Research Report no. 98

Eghosa E. Osaghae

\title{
Structural Adjustment and
}

Ethnicity in Nigeria 


\section{Indexing terms}

Structural adjustment

Politics

Ethnicity

Nigeria

ISSN 1104-8425

ISBN 91-7106-373-0

CEghosa E. Osaghae and Nordiska Afrikainstitutet

Printed in Sweden by Motala Grafiska, Motala 1995 


\section{List of contents}

Introduction. . . . . . . . . . . . . . . . . . . 5

Objectives, Scope and Method of Study. . . . . . . . . 9

Clarification of Concepts. . . . . . . . . . . . . . . 11

A Theoretical Framework ................. 18

SAP and the Adjustment of the

Nigerian Economy Antecedents.............. 23

The SAP Regime $\ldots \ldots \ldots \ldots \ldots \ldots \ldots \ldots . \ldots 28$

The Impact of SAP. . . . . . . . . . . . . . 34

Transformed Social Terrain. ... . . . . . . . . . . 34

The Aggravated Legitimacy Crisis . . . . . . . . . . . 36

SAP and Ethnicity .................... 40

Ethnicity Before SAP ................. . 40

The Impact of SAP on Ethnicity. . . . . . . . . . . . 44

Micro Ethnicity .................... 46

Macro Ethnicity..................... 52

Conclusions........................6 60

Notes........................661

References ........................662 


\section{INTRODUCTION}

Between 1986 and 1993, ethnicity went through a mix of negative and positive changes in Nigeria. On the negative side, there was an intensification of ethnic conflicts at various levels. At the inter-group level, there were violent clashes between minority groups and the dominant Hausa/Fulani in several parts of the north, notably Bauchi, Kaduna, and Plateau states over issues of trade, religion, language, culture, and domination; there was a resurgence of bloc ethno-regional conflicts which deteriorated badly after the annulment of the June 12 presidential election in 1993, leading to separatist agitations and fears that a civil war could ensue; oil-producing minority groups went on the offensive to protest their political and economic marginalization despite being the source of the country's wealth, and one of them, the Ogonis, engaged the state in a battle to assert their right to self-determination; and there were isolated clashes amongst members of different minority groups. At the intra-group level, there was an unprecedented increase in inter-communal clashes mostly over issues of a local nature, especially disputes over land ownership. The struggles for, and eventual creation of, new states and local government units in 1991 did a lot to intensify conflicts at this level. Finally, at the interpersonal level, although it was more difficult to discern conflicts of a clearly ethnic nature, it was easy to see that the levels of ethnic consciousness and the usage of ethnic connections were on the increase as diminishing resources and opportunities intensified competition for jobs, contracts and other benefits. And the importance of ethnicity for success in the informal sector which previously escaped the attention of students of ethnicity, became very prominent.

Alongside the intensification of ethnic conflicts and the salience of ethnicity in the lives of individuals was an increase in the positive uses to which ethnicity had previously been put. This mostly involved the mobilization of local capital through self-help efforts and government support, the provision of social services and other amenities by ethnic organizations and various community development associations, and the involvement of ethnic unions in urban areas in the development process. The period under review also witnessed an unprecedented upsurge in the number and activities of ethnic unions of various complexions: 'development' unions, 'progressive' unions, 'hometown' associations, social clubs, community development associations, cultural 
organizations, and 'migrant ethnic empires'. Some of these were new organizations, but the vast majority were old, sometimes moribund, associations that were invigorated to meet new challenges. The increasing importance of ethnic ties for urban dwellers was a big boost to these organizations, as more and more people were forced to heed the clarion call in the famous maxim "What else is development other than helping your hometown?” (Southall, 1988).

The fact that these changes in ethnicity coincided with the implementation of the Structural Adjustment Programme (SAP) suggests, prima facie that SAP was either responsible for them or at least had a lot to do with them. There are even more plausible empirical and theoretical reasons to suppose so. The increased reliance on self-help efforts for example, could be directly attributed to the retrenchment of the state from most areas of individual lives which is consistent with the destatization objective of SAP. The intensification of conflicts could also be directly linked to SAP, following the long-standing conventional wisdom which links the intensification of ethnicity to conditions of economic depression or recession, scarcity, and immiseration, all of which SAP entailed (cf. Chazan, 1982, 1986). As a recent statement of this thesis puts it, "The general relationship between material prosperity and ethnic conflict within multi-ethnic societies seems clear enough. Economic deterioration exacerbates ethnic tensions as reduced resources feed ethnic competition over their distribution" (Albion and Lampe, 1994:1). Beckman (1993) also links national disintegration to economic reform. There are other more general theses which link ethnicity to structural factors of the economy and politics (Schildkrout, 1974) as well as developments in the international arena, particularly global economic interdependence and improved communication (Stack, 1981). Moreover, extant studies of SAP have not only described it as the most far-reaching and consequential effort at restructuring the economy, but also point to its serious impact on virtually every facet of national life: agriculture, social services, employment, political relations, urbanization, and so on. Surely, a programme whose implementation affected social, political and economic relations in drastic and sometimes fundamental ways has to have had an impact on ethnicity which provides a context for these relations.

But these hunches and deductions are not sufficient to establish direct and causal linkages between SAP and ethnicity. To begin with, Campbell (1989) has warned that scholars should be careful not to make SAP the new 'scapegoat' by suggesting that it created the problems in which they are interested. For the most part, Campbell argues, 
SAP only accentuated extant pathologies and made manifest problems which were previously latent. Although this is the perspective from which the impact of SAP on ethnicity is approached in this study, the fact that SAP is capable of, and actually fostered new social relations and created new realities should not be overlooked. This is however a matter for empirical investigation. Another reason why a direct linkage between SAP and ethnicity might be difficult to draw in the case of Nigeria is that SAP itself was a response to a long-drawn outdeterioration in economic conditions in the country which was worsened by the global economic recession of the late 1970s and early 1980s.

As this antecedent deterioration was not only consequential for ethnicity, but actually set in motion some of the changes in social relations, attributed to SAP any linkage to be drawn has to take into account the consequences of the recession period. This should not be difficult to do because SAP cannot be meaningfully analysed in isolation of the antecedent recession which was the context within which it was implemented. In other words, economic recession and SAP constitute one continuous process rather than two periodically distinct processes, and this is the manner in which they are conceived in this study. The other difficulty in linking SAP to ethnicity is that SAP was not the only programme that brought far-reaching changes to the socioeconomic and political landscape in the period 1986-1993. There was the convulated democratic transition programme of the Babangida administration which introduced important structural and contextual changes to the political system. These changes included the imposed two-party system with its vaunted grassroots philosophy, the plethora of experimental electoral systems, the social mobilization programme, including rural mobilization schemes like the Better Life Programme, the strengthening of local government as the third tier of the federal grid, and the creation of new states and local government areas, all of which affected the hows and whys of ethnicity in significant ways.

Although many scholars are, like the authors of SAP, the World Bank and IMF which have made democratization a political conditionality for aid, inclined to regard economic adjustment and democratization (which some have also called political adjustment) as two mutually reinforcing processes (cf. Deng et al., 1991; Herbst, 1990; Bratton, 1994; and Callaghy, 1994 for a more critical view). The experience of Nigeria and other countries which embarked on both processes simultaneously is that SAP is negatively correlated with democratization; that in fact it not only stifles democratic impulses, it can only be successfully implemented by an authoritarian rather than a 
democratic regime (cf. Nyang'oro and Shaw, 1992; Onimode, 1991; Przeworski, 1991; Malloy, 1987; Olagunju et al., 1993). The contradictions and conflicts generated by a conjunction of SAP and democratization therefore can only serve to reinforce social tensions and anxieties. There were also aspects of democratization which had little or no bearing on either political or economic liberalization but had important consequences. For example, the manipulations and hiccups in the democratic transition process, especially the frequent cancellation of presidential primaries and the annulment of the presidential election of June 12 which were part of General Babangida's design to remain in power had important effects on political relations in the country.

Finally, there were the dramatic changes in the global arena-the collapse of authoritarian regimes, the new wave of democracy, the increased attention to human rights matters and in particular, the rights of oppressed, dominated and disadvantaged peoples to self-determination, the outburst of internal wars and other violent conflicts which were mostly ethnic in origin, focus on environmental and conservation matters, etc.- which had serious implications for, as well as direct and indirect influences on, ethnic relations within the country. For example, Ken Saro-Wiwa who led the Ogonis to demand political autonomy within the federation and adequate compensation for the environmental hazards and underdevelopment caused by oil exploration and refining activities in the early 1990s has pointed to three aspects of the changing global outlook which encouraged the uprising: "the end of the cold war, the increasing attention...paid to the global environment, and the insistence of the European Community that minority rights be respected, albeit in the successor states to the Soviet Union and in

Yugoslavia” (Saro-Wiwa, 1992:7).

An attempt to analyse the impact of SAP on ethnicity is not therefore as simple and straightforward as it seems at first sight. One first has to decide what to do with the other factors which also had an impact on ethnicity. Should they be regarded as intervening factors, as contributory or mutually reinforcing factors or as extraneous factors whose effects should be studied separately? Or, to pose the question in a simpler way, can the impact of SAP on ethnicity be studied without reference to these other factors? The answer will of course be no, because they throw considerable light on the impulses which induced and exacerbated tensions, conflicts, and other changes in political and social relations. This is the method adopted in this study. The focus is on how SAP impacted on ethnicity but as the empirical dimensions of this linkage are analysed, the contributions of these other factors will be emp- 
hasized as they shed more light on the formations.

\section{Objectives, Scope and Method of Study}

The impact and consequences of SAP have attracted tremendous attention among scholars as evidenced by the growing literature on the subject. Initially, the focus was on the macro-economic consequences, and the extent to which countries implementing SAP had managed to recover (balance of payments, level of investment, especially foreign investment, growth rate and GDP were major indices in this regard) and entrench market forces (cf. Vinod et al., 1991; Corbo and Webb, 1991). This highly economistic approach was in consonance with the logic of adjustment pursued initially by the IMF and World Bank which was oblivious of the devastating social and political effects of SAP. It was the alarm raised by several African scholars over the steady deterioration in the conditions of the citizens, the sporadic outbursts of violent riots in towns and cities by ordinary peoples who were made poorer, jobless, thrown out of school, hungry and sick by SAP, the resultant ground swell of opposition to the programme, and the realization that the legitimacy and stability of governments implementing SAP were in serious jeopardy, that forced the necessary change in the assessments (and packaging) of SAP. More concrete instances of the changing perceptions included the call for "adjustment with a human face" by UNICEF (see UNICEF, 1987), the formulation of an African alternative to SAP by the Economic Commission for Africa (see ECA, 1989), and the creation of a special department by the World Bank itself to address the social consequences of SAP particularly poverty and how to alleviate it (World Bank, 1990).

The impact of SAP on most sectors of national life has been studied by different scholars. In addition to the all-encompassing social and economic consequences, more specific areas like education, employment, labour relations, population, health, industry and manufacturing, agriculture, democracy, vulnerable groups-women, children, urban and rural poor-and political relations have received attention (see contributions in Adepoju, 1993; Olukoshi, 1991, 1993; Onimode, 1989, 1992; World Bank, 1990). But, in spite of the impressive array of areas and subjects covered, there has been no study that specifically tries to link SAP to ethnicity, a subject which is very central to the analysis of African politics and development. To be sure, authors like Chazan (1982, 1986; also Azarya and Chazan, 1987) and Brown (1980) have addressed the consequences of economic recession for eth- 
nicity, and others have hinted at the possible effects of SAP on ethnicity, but there has so far not been any attempt to examine the linkage in theoretically and empirically profound ways. This is what this study seeks to do. It examines how the implementation of SAP, and its macro- and micro- social, economic, and political consequences affected ethnicity at the inter-group, intra-group and interpersonal levels.

SAP was formally adopted in Nigeria in July 1986. It was originally planned as a short-term recovery programme which was to last only until September 1988. This, like the national debate which prefaced the adoption of SAP, may have been part of the strategy for getting the people to accept the programme (a short period of "sacrifice" was not too much support to give, especially if, as the people were led to believe, the programme would improve their well-being which had been in the red since the early 1980s). Thus the programme continued well beyond 1988, and was only terminated in January 1994 when, in a desperate bid to mobilize support, the Abacha administration embarked on a policy of populist nationalist economics involving an abandonment (or suspension?) of several aspects of SAP and a return to a command economy. Effectively then, SAP lasted for a period of seven years (198693). But any study of SAP has to recognize that it was neither adopted nor implemented in a vacuum. As pointed out earlier on, the economic recession which began in the late 1970s and 1980s provided the context for both the adoption and implementation of SAP. In fact, the austerity measures introduced between 1978 and 1986, which included rationalization of the labour force, reduction of imports, wage freezes and the scrapping of commodity boards were a precursor to SAP and necessary steps in that direction.

How should the impact of SAP in general, and on ethnicity in particular be studied? Loxley (1988) has identified four approaches to assessing the impact of SAP:

(1) the "before and after" approach which relates the overall performance under SAP to pre-SAP performance;

(2) the "target-instrument" approach which focuses on specific components of SAP;

(3) the "counter-factual" approach in which assessment is based on what performance might have been without SAP; and

(4) the "with-without" approach in which evaluation is based on relating performance to other economies with or without adjustment programmes.

These approaches are obviously best suited to the assessment of economic performance which is the purpose for which they have been app- 
lied, but the before and after approach appears appropriate for our present purpose. But while the "after" of SAP is easy to specify (it was adopted in 1986), the determination of the "before" is not as easy. Some scholars simply take the date of introduction as the "before" boundary, but as was emphasized earlier, the economic recession which predated SAP has to be treated as part of the SAP regime, especially when we are dealing with social formations which resulted from it, which cannot be dealt with in terms of statistical indices. To a large extent, it is this extended before and after approach, with its historical emphasis, that is adopted in this study. The "with-without" approach which is inherently comparative also provides another useful approach for the study of the impact of SAP, especially when one is interested in formulating generalizations which require comparative data.

With regard to ethnicity, the overall political, social and economic consequences of SAP will first be analysed in order to understand the transformed contexts of social formations and relations among and within groups, as well as between persons. It is within this framework that the impact of SAP on ethnicity can be better explained and understood. For example, the complication of the crisis of legitimacy which has historically disenabled the state under SAP led its managers to seek new forms of alliances in the countryside, and the competition which this engendered raised levels of ethnic consciousness at the rural level.

\section{Clarification of Concepts}

As we shall be dealing with SAP in great detail in the next section, the major concept that needs to be clarified at this stage is ethnicity as well as its descriptive categories used in this study: negative ethnicity, positive ethnicity, macro-ethnicity, and micro-ethnicity. We shall also present a brief overview of the ethnic terrain in Nigeria.

Ethnicity may be defined as the employment or mobilization of ethnic identity and difference to gain advantage in situations of competition, conflict, or cooperation. Two points in this definition should be emphasized. The first is that contrary to popular perception, although its competitive and conflictual aspects are more pronounced, ethnicity is not always conflictual; it can also involve cooperation between members of different ethnic groups. The other is that in situations where it comes into play, ethnicity is consciously employed by the actors involved. As it were, it is not simply the awareness of ethnic differences that produces ethnicity, but the consciousness of the purposes to which the differences could be put. The conditions which lead to the employment 
or mobilization of ethnic identity and how the ethnic strategy is articulated are therefore crucial to understanding the phenomenon. 
Central to the definition of ethnicity is ethnic differentiation which ensues from multiethnic settings. To understand ethnicity therefore, one has first to define the ethnic group which underlies it. An ethnic group is a group whose members share a common identity and affinity based on common language and culture, myth of common origin and a territorial homeland, which become the basis for differentiating 'us' from 'them', and upon which people act. The ethnic group is therefore a mix of objective and subjective criteria, though for purposes of analysing ethnicity which is behavioural and dynamic, the subjective aspects of identity articulation, the boundaries assigned to the ethnic groups by the 'insider' and 'outsider', and the differences given emphasis, all of which provide the basis for action, are emphasized.

Ethnicity exists and can be analysed at three related levels: intergroup, intra-group, and interpersonal. Inter-group ethnicity which is the most popular conception in the literature, is the most all-encompassing level, and usually involves the mobilization of the most generic ethnic identities and other bloc identities with which they are often closely related: regions and religious groups. In Nigeria, certainly, ethnicity at this level involves, in addition to the real ethnic groups, the geopolitical regions (North, South, East and West) and the religious cleavages (principally that between Christians and Muslims) which have been the historical contexts within which ethnic identities have been articulated and reinforced. In recognition of this fact, it has been argued that ethnicity does not exist in a pure form, and its relationship with the intergroup level that the roles of the ethnic entrepreneurs or the élites who decide to mobilize amongst people belonging to different subgroups who may not have been aware of the uses to which their interconnections could be put by alluding to myths of common origin or fostering standard languages or establishing cultural and political associations are most pronounced. This is why most ethnic groups today are described as new and emergent (cf. Lema, 1993). The main actors in intergroup (and intra-group) ethnicity are the ethnic associations which take on a variety of forms. The most popular and all-inclusive are the ethnic and cultural unions which are formed mostly in urban areas. These played and continue to play front line roles in the process of ethnicization which transformed ethnic awareness to ethnic consciousness and unity. There are also the hometown and community associations which are mostly active at the intra-group level. In some cases, inter-group ethnicity is propagated by political parties and other manifestly political interest groups. This was true of the First and Second Republics in Nigeria in which the main political parties were ethno-regional in cha- 
racter and sought to maximize the interests of the ethnic groups they represented. Finally, traditional authorities—kings, chiefs, elders, etc.-who usually symbolize group identity and unity also serve as entrepreneurs and brokers of group interests.

Intra-group ethnicity involves subgroups whose members speak dialects of generic language groups or subgroups separated from their kith and kin by administrative structuring and natural barriers. Most ethnic groups are congeries of several subgroups. The Yoruba for example are a composite of the Egba, Ekiti, Ondo, Oyo, Ijesha, Ilaje and so on, while the Ogonis comprise three major subgroups which speak different dialects of the Ogoni language (Gokana, Khana and Tai-Eleme) and are further subdivided into six clans each headed by a chief (Gbeneme). Usually, what comes out as bloc ethnicity at the inter-group level would have involved contestation at this level, that is between leaders of the subgroups, and where it is not possible to reconcile differences, there can be as many positions taken by the ethnic group as there are subgroups. Many scholars acknowledge the importance of intra-group ethnicity because it helps to explain why ethnic boundaries are never fixed and why ethnic unity is a dependent rather than an independent variable (cf. Brass, 1985).

One major conceptual problem in analysing inter-group and intragroup ethnicity has to do with whether there are constitutive ethnic interests and, if there are not, whose interests are to be regarded as those of the group. The popular position is that what is mistaken for group interest is actually the selfish interest of the élites, which in Nigeria include the traditional authorities (cf. Smith, 1981; Hechter and Levi, 1979). But the process of articulating ethnic interests is more complex than this. The point to begin from is that, as is the case with other collectivities and communities of interest, there is always a plurality of competing interests within the ethnic group or subgroup (and this includes the elite ranks as well) and the articulation of particular interests at any point in time does not suggest that there is no opposition or that other competing interests are no longer important. One of the major functions of ethnic associations which we have said are the main actors at these levels is to reconcile these competing interests and articulate interests which not only enjoy wide agreement and support but engender group unity and solidarity.

In this process, the élites, as patrons and benefactors, usually have an edge over the others in getting the group to accept their points of view, but this is neither automatic nor imposed; processes of negotiation and bargaining are involved, and they do not always succeed. Instances 
abound in Nigerian cities where open disagreements have led to splits in ethnic associations along elite-non-elite lines, with the polarized associations pursuing opposed interests in the name of the same ethnic group (Osaghae, 1990). The point therefore is that the articulation of group interests is a dynamic and highly contested process, but this does not mean that group interests are false or mistaken. Besides, there are common interests shared by members of groups which centre, amongst others, on the propagation of culture and language. It is not surprising then that in mobilizing ethnic unity and solidarity, the entrepreneurs place emphasis on these objective commonalities, as well as on the fears and anxieties of members (Osaghae, 1991).

Finally, interpersonal ethnicity involves the employment of ethnic differentiation in relations among individuals or small groups of individuals. It is at this level that the situationality of ethnicity which has been stressed by many authors is most clearly seen (cf. Okamura, 1981). Just as the fact of ethnic plurality does not ipso facto produce ethnicity (which as we have defined it is consciously employed or mobilized in particular situations), so the fact of the individual's ethnic identity does not mean that he or she will employ it to serve his or her interests. The individual has an array of identities to choose from: class, gender, political party, professional, and so on, all of which he holds in addition to his ethnic identity. He decides to adopt any of these identities based on his perception of the situation in which he is relating with others, especially his perception of the identities and strategies employed by them.

Thus, it is possible for the individual's ethnic identity to remain dormant for a long time, as long as the other identities and strategies based on them are sufficient to serve his needs. This does not however mean that ethnicity has vanished, for dormancy simply means that the individual has not found it necessary to employ the ethnic strategy. The situationality of ethnicity not only explains why it is variable and often oscillates between pervasive salience and virtual disappearance, it shows why it is wrong to assume that people in multiethnic societies are obdurately ethnic. It also shows why it is misleading to assume that only the élites or members of the privileged classes can employ the ethnic strategy. The fact that it is these actors who are most acutely conscious of the efficacy of the ethnic strategy because it is they who are in the thick of political, social and economic competitions does not mean that others cannot also decide to employ the strategy if the situation calls for it. In general, ethnicity is most likely to be salient at the interpersonal level when individuals perceive their ethnic ties as systemati- 
cally affecting their position and fate in the socioeconomic and political structures of their state and society (Rothschild, 1981).

What ties ethnicity at the three levels together is ethnic identity. According to Erikson (1968:22), identity is "a process located in the core of the individual and yet also in the core of his communal culture, a process which establishes, in fact, the identity of these two identities". The intricacies of the linkage between individual and group ethnicity are identified by Young (1976:20) thus: "The quest for belonging and self-esteem is pursued through communal group affiliations. Fear, anxiety and insecurity at the individual level can be reduced within the womb of the ethnic collectivity; at the same time, threats to the security of the group provide a mobilizing imperative for its members".

Nevertheless, as between the individual and group ethnic identities can shift from one level to another. The shifts are usually between macro- identities which have to do with the all-encompassing bloc identities and micro identities which involve subgroup identities and find territorial anchor in village, clan, or community formations. These levels of identity can be further employed to classify ethnicity into microethnicity which corresponds with intra-group and interpersonal ethnicity, and macro-ethnicity which has to do with inter-group relations. The final distinction we shall make is between negative ethnicity and positive ethnicity. The popular connotation of ethnicity is that it is dysfunctional because of its exclusivist and discriminatory claims, and that, as such, it is a threat and hindrance to national integration and economic development. In these negative terms, ethnicity is a problem to be eradicated if possible or allowed as minimum expression as possible where it cannot be helped.

Because this is the popular and established connotation, the notion of positive ethnicity appears to be a contradiction in terms: how can ethnicity be positive? But it can be if the focus shifts from ethnicity as a means of accumulation and competition over common resources to ethnicity as a means of producing surplus and complementing the activities of the state which are never sufficient to meet the demands of many citizens especially the neglected rural majority. The generation of local capital, provision of amenities and services like awarding scholarships, building schools, hospitals, post offices, and establishment of cottage industries which various ethnic associations have engaged in through self-help efforts can be regarded as positive. Indeed, such undertakings which are not negatively competitive can provide a basis for forging cooperative links amongst members of different groups, and suggest that ethnic diversity can be harnessed for positive ends (see also Otite, 
1990:167ff). It may be argued that supposedly self-help undertakings involve direct and indirect transfers of state resources to local purposes and that they sometimes provide the basis for prebendal politics, but this is not always the case, and it is known that members of ethnic associations in towns take the task of developing their home areas very seriously.

To complete this conceptual exercise, let us briefly summarize the ethnic terrain in Nigeria. The key to understanding the ethnic composition of the country as well as the dynamics of the relations which proceed therefrom is the country's federal system which was adopted largely to accommodate the complex diversities in the country. The exact number of ethnic groups in the country is not known partly because scholars are not agreed on whether dialects of generic languages should be regarded as distinct ethnic groups or subgroups, but estimates vary from the official estimate of 248 to 374 (Otite, 1990) and 550 to 619 (Wente-Lukas, 1985). These groups are broadly classified into majority groups and minority groups, a classification which evolved from the regionalisation of the country under colonial rule. The three major groups-Hausa/Fulani, Yoruba, and Igbo-were the fulcrum of the three regions-North, West, and East respectively-into which the federation was divided until the 1960s (a fourth region-the Mid-West-was created out of the Western region in 1963), and this has historically made members of these groups the dominant actors in political and economic relations. All the other groups are minority groups, although some (like Edo, Ijaw, Tiv, Igala, Nupe, and Urhobo) are regarded as 'medium' groups. Members of these latter groups have historically engaged in the struggle to redress what they allege to be majority domination of the geopolitical regions and the federation as a whole.

Superimposed on these discrete ethnic groups are the geopolitical regional categories which have historically provided the context for bloc ethnicity. In fact, many commentators and analysts regard conflicts between the North and South, North, East and West, and coreNorth and Middle Belt and the shifting political alliances and coalitions among leaders of these regions as the core ethnic problems of the country. Others add Christian-Muslim cleavages and the new form of regionalism which emanates from the exclusivist tendencies of the states, popularly referred to as statism. In the strict conceptual sense these cleavages do not constitute ethnic groups, but to emphasize their interconnections with ethnic groups (the facts for example that references to these regions are usually references to the three major ethnic groups 
which dominated their affairs from inception) ${ }^{1}$ and the fact that they underlie perceptions of ethnicity, they may be regarded as "ethnic categories". These interconnections and perceptions which are quite complex and deep-rooted have been dealt with by several authors (cf. Coleman, 1958; Ekeh, 1990; Graf, 1988; Osaghae, 1986). Only a brief summary is necessary here.

The North-South cleavage which underlies discussions of ethnic domination in the country (so-called Northern domination), of power sharing, and resource allocation, is the deepest and most historically enduring political cleavage in the country. Its roots lie in the divergent orientations of the two regions dating back to the precolonial period which resulted in the Islamization of most parts of the North and the Westernization of most parts of the South, the British administering of the two parts differently as even after they were amalgamated in 1914, the gross inequalities between the two parts in educational advancement, manpower, resource endowment, size and population. Other critical cleavages are those between the East (Igbo) and West (Yoruba), core-North (Hausa/Fulani) and the Middle-Belt (mainly minorities of the Benue/Plateau and Southern Zaria axis), and between the Igbos and Eastern minorities which were reinforced by the civil war. ${ }^{2}$ Then there is the Muslim-Christian cleavage which reinforces regional and ethnic cleavages. First, it reinforces the division between the North (which is said to be "predominantly" Muslim) and South (said to be "predominantly" Christian). ${ }^{3}$ In the late 1970s and 1980s, this cleavage was at the heart of major disagreements between 'Northerners' and 'Southerners', although alliances between Northern Muslims and Southern (Mainly Yoruba) Muslims as well as between Southern Christians and Northern (mainly Middle Belt) over the sharia, secularity of the country, and other issues were beginning to assume greater political significance.

The religious cleavage was even more intricately tied to the ethnic one in the North where the Hausa/Fulani majority are dominant both in the ethnic and religious senses; in fact some consider the Islamic component of Hausa/Fulani domination which dates back to the jihad of 1804 and the subsequent attempts to extend the suzerainty of the Soko to caliphate to all parts of the North (and even the country as a whole) to be a far more important basis for resistance by the minorities than simply the ethnic one. ${ }^{4}$ So the minorities in the North are not simply ethnic; they are also non-Muslim and mainly Christian. Moreover, there is a tendency on the part of members of minority groups who are Muslim to regard themselves as part of the politically 'privileged' (Hausa/Fulani) North. 
The ethnic groups are accommodated in thirty states, a federal capital territory, and 589 local government areas. Thus there are three levels at which ethnicity takes place. First is the federal level at which macro-ethnicity involving the three major ethnic groups and their regional constituencies (as well as religious constituency in the case of the North) on the one hand, and these and the minority groups on the other is dominant. Next are the state and local levels where macro-politics mainly involving the minority groups and micro politics involving subgroups are dominant. Within these contexts, the major impetus for ethnicity at the inter-group, intra-group, and interpersonal levels has been the inequalities amongst the groups in terms of socioeconomic advancement (education, employment in the public and private establishments, and access to and control of important sectors of the national economy by members of the group), resource endowment, size and population, and access to and control of political power which is the major means of social reproduction in the country. The extent to which SAP affected these inequalities by for example providing an avenue within which some of them could be redressed (the privatization/commercialization component of SAP was perceived as an opportunity to redress the imbalances in the control of the country's economy) is therefore one good measure of its impact on ethnicity.

\section{A Theoretical Framework}

The central question in most analyses of ethnicity is whether ethnicity is a political or cultural phenomenon. Although this question is mostly raised at the level of inter-group and intra-group ethnicity, it provides a useful point of departure for any theoretical explication because it raises issues of the nature of ethnicity, its predisposing factors, and its consequences. There seems to be general agreement that although ethnic identity has a largely cultural basis, it is not a cultural phenomenon (cf. Brass, 1991). It is rather political, not only because its mobilization and deployment are directed at the determination of who gets what, when and how, but also because it is highly consequential for the political process. This conception further presupposes that ethnicity is problematic because it is dysfunctional, but as was pointed out above, this is not always the case. Unlike the cultural perspective which assumes a certain measure of naturalness or automation about ethnic action, the political perspective does not take it as given, and is more interested in how and why ethnicity comes into play. 
Several explanations have been offered for ethnicity and why it becomes salient and/or pervasive. These include:

(1) state actions and policies which promote or perpetuate economic, social, and political inequalities among ethnic groups especially in countries which have been described as "ethnocratic"

(2) competition over scarce resources amongst members of unequal groups;

(3) the existence of minorities;

(4) the proven efficacy of the ethnic weapon in obtaining positive responses to demands on the state whose managers fear that ethnic demands which are not responded to are a threat to the stability of the state;

(5) the low levels of alternative competitive identities and consciousness, especially those related to class, a consequence of low levels of industrial and capitalist development;

(6) high levels of illiteracy and poverty which are conducive to manipulations of ethnic differences by members of the privileged classes and the state;

(7) the absence of or limited social security and social welfare policies and programmes; and

(8) intensive politicization due to the zero-sum manner of political competition, especially over control of the state, which creates anxieties, distrust and acrimonies over representativeness of core government agencies-armed forces and public service and control of the economy-and introduces ethnic considerations into most issues, including education (for the various perspectives on ethnicity, see Cohen, 1974; Despres, 1975; Young, 1976; Enloe, 1973; Kasfir, 1976;

Rothchild and Olorunsola, 1983; and Brass, 1991).

These predisposing and reinforcing factors are given different emphasis by scholars, but given the complexity of ethnicity, none of them can provide an adequate explanation on its own. In most African countries, all of them apply, though the role of the state, peripheral capitalism, and pervasive illiteracy and poverty tend to be given emphasis (see Nnoli, 1978, 1989).

The theoretical premise of this study hinges on two related factors: the materialist basis of ethnicity and the role of the state. The two factors are closely related because the character of the state is determined and conditioned by the prevalent economic and social formations. Authors like Ake (1985) and Hyden (1986) attribute ethnicity in Africa to the prevalence of precapitalist modes of production, precisely the fact that, as Hyden says, the uncaptured peasantry who constitute the vast 
majority of the population in most countries, continues to be bound by the "economy of affection". For Ake (1985:11):

The objective basis of ethnicity lay ultimately in the limited development of commodity relations and, on a more fundamental level, in the limited development of productive forces. For ethnic consciousness is the correlative consciousness of the precapitalist social relations of rural Nigeria which are essentially a mechanistic solidarity. But this explanation is faulty on three grounds. First, it suggests that capitalist development or capture of the rural areas will make ethnicity less salient, a claim which is not supported by the experience of advanced capitalist countries like Belgium, Canada and the USA where ethnicity remains salient, notwithstanding the attempt by scholars like Gans (1979) to treat ethnicity in these countries as "symbolic ethnicity". As this study hopes to show, the increased penetration of capitalist forces in rural areas under SAP heightened rather than reduced ethnic consciousness and tensions.

Second, by making ethnicity a vestige of the traditional (precapitalist) past which is giving way to capitalist forces, the salience of ethnicity in the modern-capitalist penetrated urban sector is only explained in terms of the fact that urban dwellers "are still part of the social formation and cannot be immune from the forms of consciousness which arise from powerful objective forces in the formation and which dominate the consciousness of the vast majority of people" (Ake, 1985:26). Not only does this run counter to the urban-determinism often assumed in the growth of ethnicity, it fails to see that ethnicity is not simply a vestige of the traditional past. Nonetheless, it points to the inter-connectedness between urban and rural ethnicity which some authors who treat the two categories separately deny (see Osaghae, 1994a). Finally, the explanation, especially as stated by Hyden seems to assume that ethnicity is natural and that the uncaptured peasant has a fixed ethnic consciousness, and, as such, fails to see that it is dynamic and situational.

These criticisms are not to deny that ethnicity has a lot to do with the dynamics of the mix of capitalist/precapitalist social formations, but to say that the emphasis on precapitalist formations is overstressed. The factor of capitalist penetration itself, and the form it takes, is even more crucial. As is well acknowledged, capitalist growth and development engender inequalities amongst competing classes and groups which, because of the advantages and disadvantages that they confer, become a basis for political action. Thus, it can be expected that capitalist expansion in the rural areas under SAP will be conducive to the rise of 
ethnic consciousness and exacerbation of nascent conflicts. In the modern sector, the extent to which the implementation of SAP reinforces or reduces extant conflicts amongst groups, regions and states, or creates new ones will also seriously affect the ethnic relations. Structured inequalities have a lot to do with power relations and the location of groups within them, a point we shall come to shortly. It is within this context of inequalities that the ethnic weapon or strategy becomes functional and is employed by individuals and groups (see also Rothschild, 1981). I should stress however that it is the perception of inequality held by actors rather than the actual inequality that leads to action (in some cases, inequalities are exaggerated to justify action or mobilize group solidarity). Moreover, it is not so much deprivation or disadvantage that engenders ethnic action; it is rather the prospects for advancement from them.

The other important explanation for ethnicity within the materialist framework is the structure of power relations, which has to do with the centrality of the state in social reproduction in most African and third world countries (see Bayart, 1993 for a good historical account of this situation). According to Ake (1985:5):

Power is everything, and those who control the coercive resources use it freely to promote their interests, including the appropriation of surplus. For those who control force, entrepreneurial activity is unnecessary; for those who do not it is often futile. So we have a singularly unproductive capitalism in which force is the means of accumulation and wealth is dissociated from entrepreneurial activity.

The possibility that state power can be made the preserve of one or a few ethnic or other sectional groups, and that it can be employed to further the interests of only people from such groups (which makes the state party to conflicts between groups rather than a neutral arbiter as liberalists assume) explains the anxieties that often attend the structure of state power and succession to it.

This possibility exists and has been actualized in several countries in Africa because, as Ake explains, the post-colonial state lacks autonomizing mechanisms which can insulate it from being made to serve group or class interests or being prebendalized (see also Joseph, 1983, 1987). As a report by the African Centre for Applied Research and Training in Social Development (ACARTSOD) puts it, "The African state has not achieved neutrality or autonomy as it concerns the struggle of groups and individuals in the society. Thus control of it enables individuals and groups to achieve their interests at the expense of other groups and individuals" (ACARTSOD, 1990:25). As a result, control of state power is the most crucial object of political competition because any group 
excluded from it perceives itself to be excluded from development, and its members from socioeconomic privileges and benefits since the state is the largest employer of labour and dispenser of patronage:

Contending groups struggle on grimly, polarizing their differences and convinced that their ability to protect their interests and to obtain justice is coextensive with their power...In this type of politics, there is deep alienation and distrust among political competitors. Consequently, they are profoundly afraid of being (under) the power of their opponents. This in turn breeds a huge appetite for power, which is sought without restraint and used without restraint (Ake, 1985:10; see also Post, 1991:37).

The location of a group in the power grid which is measured in terms of positions in central government held by members of the group and how critical such positions are, and therefore, the group's political leverage, is crucial in explaining the political relations of its members with members of other groups. But the actual structure or composition of government is not as crucial as its actions and policies, and the extent to which these redress or reinforce imbalances among groups. Following the footsteps of the colonial state, post-colonial governments have entrenched manipulations of ethnic differences and inequalities as a legitimizing tool. Thus, citizens continue to be defined in terms of their ethnic origins, and attempts to redress the disadvantages of less developed groups are tied to loyalty to the ruling coalition. Actions like these not only legitimize ethnicity and encourage demands by ethnic groups and ethnic interests, they reinforce the perception that a group has to have a part, and be represented in government before it can hope to enjoy the privileges available to others.

To summarize, ethnicity is largely to be explained in terms of the perceptions of socioeconomic and political inequalities among members of different ethnic groups, and the extent to which state actions and policies legitimize the ethnic strategy and redress or reinforce these inequalities. The fact that the state is the major means of social reproduction and that its apparatuses could be made to serve the interests of one or a few groups to the exclusion of others makes its control the central object of political competition which is attended by what Ake calls the "politics of anxiety". Under situations of economic decline and diminishing resources, this anxiety is heightened and could lead to the intensification of extant and latent ethnic conflicts. It is within this framework that this study examines the impact of SAP on ethnicity in Nigeria. 


\section{SAP AND THE ADJUSTMENT OF THE NIGERIAN ECONOMY ANTECEDENTS}

The long and tortuous road to the introduction of SAP began by the close of the 1970s when, after a decade of prosperity from an oil boom, signs of economic decline-trade deficits, budget deficits, inflation and balance of payments problems-were considered serious enough to warrant government intervention. ${ }^{6}$ With oil production, the backbone of the economy, falling from 2.1 million barrels per day (mpd) in 1977 to 1.5 million in the first quarter of 1978 , balance of payments from 1.5 billion Naira in 1977 to -7.4 million Naira in 1978, and budget deficits rising from -427 million Naira in 1975 to -1943 million Naira in 1978, it was time to try to arrest the imminent crisis. The federal government introduced austerity measures in the 1977 and 1978 budgets. These measures included the introduction of fiscal controls, restriction on imports, especially of consumer items, increase in tariffs, massive cuts in capital expenditure and expenditure on the social sector, particularly education, retrenchment of workers and the introduction of new taxes. To mobilize popular support, price controls were introduced to check inflation, and self-reliance and increased productivity were offered as the main economic goals within which programmes like "Operation Feed the Nation" were introduced to involve the people in economic recovery. To stem the balance of payment deficit, the government was forced to take a loan of 1.7 billion USD from the Eurodollar market. This was the beginning of the external debt problem that escalated in the 1980s and 1990s. However, through these and other deflationary measures, there was a momentary respite as the economy seemed to have recovered by the time the civilian administration of Shehu Shagari was sworn in October 1979 (by that year there was a 7 per cent reduction in imports, external reserves rose to over 3 billion USD, and a trade surplus of over 5 billion USD was recorded in 1980). But it was obvious that a more coherent and longer term therapy was needed to put the economy in shape. The measures implemented by the Obasanjo administration were only a stop gap. A lot therefore depended on the new civilian administration.

The profligate and corrupt civilian administration of the Second Republic (1979-1983) proved incapable of dealing with the economic crisis which was compounded by the deep recession in the global economy in the early 1980s and the shocks in the oil market. In essence, 
the crisis in the national economy only worsened. Although they do not tell the whole story and are sometimes unreliable, macro-economic statistics provide a good measure of how badly the economy sank. With the glut in the world market, crude oil production fell steadily from $2.056 \mathrm{mbd}$ in 1980 to $1.434 \mathrm{mbd}$ in 1981 and $1.229 \mathrm{mbd}$ in 1982 . There was a corresponding decline in revenue collected by the federal government: from 15 billion Naira in 1980 to 12 billion Naira in 1981, and 11 billion Naira in 1982. The net value of exports declined from over 13 billion Naira in 1980 to 7.5 billion Naira in 1982; GDP fell by 5.9 per cent in 1981 (at 1977/78 prices) and by 3.4 per cent in 1982; external debt rose from nearly 9 billion USD in 1980, to nearly 13 billion USD in 1982 and 18.5 billion USD in 1983; trade deficit was put at 2.1 billion Naira in 1982, with import bills at over 12 billion Naira, and by the middle of 1983, the total external reserve was barely enough to pay for one month's imports at the prevailing rates; etc.

The state of the domestic economy was no less devastating. Workers, especially primary school teachers in the states, were owed arrears of salaries; prices of commodities and services, including food items, rents, education and health care, were permanently rising as inflation which ranged between 30-50 per cent during the period was out of control; huge budget deficits were recorded by the federal and state governments; the manufacturing and industrial sectors which relied mainly on imported raw materials and technology were seriously affected by the changing economic fortunes and had to operate far below their productive capacities which led to shutdowns and retrenchment of workers; etc. But in typical neocolonial fashion, when the federal government decided to respond to the crisis, and turned to the international monetary bodies, it was the external dimensions of the crisis and macro-economic growth, not the plight of the people that was considered crucial.

That the Shagari administration failed to salvage the economy was not for want of trying. In 1981, it set up a commission on parastatals which not only recommended the privatization of most public corporations and expansion of the role of the private sector, but also identified structural adjustment of the economy (directed in its view towards selfreliance) as the only meaningful response to the crisis. Efforts were made to increase non-oil exports, including a two-year contract which was signed with Brazil in 1982 to export rubber. Then in April 1982, in what was the most important concerted response to the crisis but which many argued came too late, the government passed the Economic Stabilization Temporary Provisions Act. In orientation, the act was like a continuation of Obasanjo's austerity policy, as it offered only 
short and medium term fiscal and monetary measures, relied on increased government regulation, and hinged the new measures on selfreliance. In addition to further curtailing imports and reducing government expenditure, the act introduced stringent import and foreign exchange controls, and sought to boost local production of food and manufactured goods, improve the foreign reserve situation, and make the economy more self-sufficient.

These measures which reinforced the intervention of the state in the economy (indeed, the state was now more involved in the sales and distribution of essential commodities) were completely out of tune with the new economic orthodoxy favoured and imposed by the Bretton Woods institutions on insolvent underdeveloped countries which ran to them for help. The new orthodoxy embodied in the economic recovery and structural adjustment programmes designed by these institutions held state intervention and control, as well as bloated public sectors responsible for the economic woes of these countries and recommended a reduction of state involvement and control, entrenchment of market forces, and increased foreign investment as the only solutions (for a discussion of the conceptual underpinnings of SAP, see Olukoshi and Nwoke, 1994). Thus, with her hackneyed package of economic nationalism, Nigeria's application to the IMF for an extended stabilization loan of between 1.9 and 2.4 billion USD was not successful. In negotiations with IMF officials, the government was not willing to accept the conditionalities of devaluation, trade liberalization, privatization, and so on.

The inability of the Shagari administration to deal with the economic crisis was one of the major reasons given by the military junta which overthrew it in December 1983. Believing that this inability was not due to inappropriate policies but indiscipline, corruption, and mismanagement which prevented the policies from being implemented, the Buhari administration continued with populist and nationalistic economic policies similar to those in the 1982 Act, but pursued these in the most authoritarian ways. To check indiscipline in national life the regime launched a "War Against Indiscipline". In most of its actions the regime seemed to believe that curtailment of individual liberties and freedoms was a necessary condition for economic recovery. Its negotiations with the IMF were not successful because, like the administration before it, the Buhari administration rejected the conditionalities. But it made some efforts to impress the IMF by for example raising the debt service ratio to 44 per cent of national revenue in 1984 and devaluing the Naira by 14.7 per cent between January and June 1985. In 
essence, the regime basically continued with a command economy approach, albeit a more rigorous, disciplined and ingenious approach. It introduced a countertrade policy to conserve scarce foreign exchange and procure vital imports, especially raw materials for the ailing industries, drastically reduced expenditure on health and education, froze wages and employment, changed the national currency in April 1984, and rationalized government establishments and parastatals, which led to massive retrenchment of workers, and so on.

But the economy continued to be in deep crisis as foreign exchange remained scarce and the GDP continued its average decline of 3.2 per cent annually since 1980. It was against this background that the Babangida administration which forcibly succeeded the Buhari regime in August 1985 finally decided to adopt and implement SAP. Like its predecessors, the new regime began with a spell of austerity measures, and even went further to declare a state of economic emergency in October 1985. Although it acted carefully and sought to retain the people's confidence and support by throwing open to debate burning economic issues like taking an IMF loan and accepting its conditionalities, the regime also made efforts to win the confidence of the IMF by actually implementing some of its recommendations. In the 1986 budget, fuel subsidy was cut by 80 per cent, and in April a plan to sell off government's shares in several hundred federal and state government parastatals and scrap commodity boards was announced. Then finally, in a bid to secure external support for debt rescheduling and fresh loans, on 27 June 1986, the decision to introduce SAP from July 1986 was announced.

In discussions of the antecedent economic recession and forerunner policies to SAP, the popular concerns have been to show why they inevitably led to SAP or at least necessitated a long-term and fundamental restructuring of the economy. Some more discerning authors go further backwards in time to the very foundations and structure of the country's neocolonial economy-the inappropriateness of foreign technology and raw material based import substitution industrialization, the bloated public sector which is saddled with inefficient capital-intensive enterprises, the excessive intervention by the state even in the private sector, the dependence on oil and relegation of the agricultural and food sectors (the Economic Commission for Africa (ECA) reported in 1982 that Nigeria recorded zero growth in agriculture between 1960 and 1980), inappropriate monetary and fiscal policies, pervasive corruption and inefficiency of government officials and bureaucracy, the dominance of foreign capital, dependence on imports, and so on (cf. 
Bangura, 1991; Olukoshi, 1993; Onimode, 1988). What is interesting is that the interpretations of the economic crisis and the rationale for structural adjustment offered by most African scholars differed markedly from those of the Bretton Woods institutions, and the debate has remained a key feature of the literature on SAP.

But this is not our immediate concern. What concerns us right now is that the crisis and attempts to resolve it were not all about macroeconomics, recovery and stability. They had profoundly devastating effects on the ordinary people, especially the poor and underprivileged in the urban and rural areas. Many workers were retrenched, salaries were no longer regular and were unpaid over long periods, galloping inflation ate deeply into purchasing power, reduction of government expenditure on health and education raised social costs beyond the reach of most people, foreign exchange scarcity meant that hospitals continued to lack essential drugs and equipment, scarcity of food and astronomical increases in the prices of commodities inflicted hunger and malnutrition, life and property became most insecure as crime increased, and many urban dwellers were forced to return to their villages. As expected, the situation made the people fight. Labour groups, professional associations, students, market women, and other organized groups confronted the state through strikes, demonstrations and riots, managing to wrest some palliative concessions (like the success of the 1978 students riots to stop plans to raise costs of university education, the success of the doctors' strike of 1984 to get government to allocate 5 per cent of the 1985 budget to health, although only 2 per cent was eventually allocated, the increase in the national minimum wage to 125 Naira, and the introduction of a special salary structure for universities), but these could not withstand the repressive and authoritarian tactics of government.

But while the people suffered, there were those who profited from the recession and government policies. The import licence regime in the Second Republic produced a new class of wealthy men and women and enabled the strengthening of political and class ties. Bala Usman (1986:2-3) has also pointed to the huge profits recorded by multinationals in spite of low turnovers: from 1982/83 to 1983/84, the profit of the United African Company (UAC) increased from 13.6 million to 30.9 million Naira; that of Paterson Zochonis rose from 8.7 million to 13.4 million Naira; and Mobil Oil's from 19.3 million to 26.0 million Naira. In spite of these profits, workers were retrenched on a massive scale. This pattern of "winners" and "losers" was to be accentuated under SAP. So also were the authoritarianism of the state 
and the sufferings, immiseration and protests by the people. It is for these reasons that, as was stressed in the discussion of the methodology of this study, the economic recession period that preceded SAP cannot be divorced from an analysis of the impact of SAP. We shall consider how the changing social, economic and political landscape engendered by recession affected ethnicity when we come to examine the impact of SAP on ethnicity.

\section{The SAP Regime}

SAP was finally introduced in July 1986. It was originally scheduled to last only until June 1988, but it carried on through to the end of 1993. The programme was an orthodox IMF package in every respect, but to get the highly nationalistic attentive public to accept the programme, its adoption had been preceded by a national debate or "plebiscite by newspaper" Legum (1987:B 125). This gave the impression that the SAP was home-grown, rather than imposed. The main objectives and instruments of SAP have been well summarized by Forrest (1993:213) thus:

1. Strengthen demand management through monetary, fiscal, and wage policies;

2. Stimulate domestic production by encouraging non-oil exports and by reducing dependence on imported goods through changes in relative prices (notably a lower exchange rate), tariff rationalization, and export incentives

3. Reduce public regulation and administrative control by the reduction of subsidies, price control, deregulation of the financial sector, and trade and payments liberalization;

4. Rationalize the bureaucracy and public sector projects, and commercialize and privatize public corporations and companies;

5. Reschedule the external debt so as to shift the main burden of debt servicing to 1991 and beyond.

These constituted the mainstay of the SAP regime which lasted until December 1993. A critical reading of the components shows that economic growth and recovery, fiscal and monetary balance, fostering more conducive conditions for foreign capital and international trade, and easing the external debt burden were the underlying objectives of SAP. The human side of adjustment, especially the social costs, did not seem to matter, and this caused the programme to be socially devastating. Thus, even where human material well-being could be inferred from the logic of SAP-as in the declared objective of bettering the lot 
of 'productive' rural dwellers as opposed to urban 'parasites'-it would be only insofar as this boosted increased productivity for export. Currency devaluation, removal of subsidies, rationalization of the bureaucracy, privatization and commercialization, and the various monetary policies, all were approached from purely economistic and efficiency points of view.

As a backdrop for assessing the impact of SAP in specific areas, we shall first consider the overall state of the economy which was its primary focus. One critical component of SAP which was most devastating was the massive devaluation of the Naira. Through the operations of the foreign exchange market and distortions created by parallel (or black) market activities, the value of the Naira to the Dollar fell from one in 1985, to 3.81 in March 1987, 4.21 in April 1988, 7.48 in April 1989, and 22 in December 1993 (by which time it was 45-50 in the parallel market). Devaluation failed to stimulate non-oil exports or attract foreign capital as was anticipated. Instead, it raised the prices of imports on which manufacturers and industries are dependent thereby forcing further reductions in capacity utilization (which was down from 30 per cent in 1986 to 25 per cent in 1987, recovering marginally in 1988 and 1989 when it rose to 35 per cent and 40 per cent respectively), further retrenchments, and sharp increases in prices of commodities. The removal of so-called subsidies on fertilizers and petroleum products-which in actual fact simply meant bringing up domestic prices to the level of international prices but without a commensurate alignment of income levels-also helped to raise prices, and make life much more difficult for the ordinary people. The removal of subsidy on petroleum products led to violent riots, strikes and demonstrations which were repressed by police and military force.

Deregulation in the banking sector made for higher interest rates which increased by between 60 and 80 per cent. The consequent higher lending rates were a disincentive to manufacturers and small and medium scale entrepreneurs. The privatization and commercialization component was handled by the Technical Committee on Privatization and Commercialization (TCPC) which, in accordance with Decree 25 of 1988 , was to fully privatize, partially privatize, fully commercialize, and partially commercialize over 100 enterprises which government either owned fully or had controlling shares in. The sale of shares was expected to yield over 200 million Naira and stimulate private sector initiative and investment. Like the indigenization programme introduced in the 1970s and which remained in force until SAP, privatization provided another opportunity for the highly contentious issue of the 
ethnic dimensions of the control of the national economy to be placed on the political agenda. This was more so because privatization did not only have to do with selling government shares in parastatals, it also involved the expansion of private sector participation in areas formerly monopolized or dominated by government (and multinationals). These included civil aviation, oil exploration and exploitation, the liquified natural gas project, the aluminium smelter project, highway development, housing, urban mass transit, and education. We shall examine the ethnic dimensions of the politics of privatization in the next section. The full or partial commercialization of agencies like the National Electric Power Authority (NEPA), Nigerian Railway Corporation, state government water corporations, Nigerian Telecommunications Company, Nigerian Postal Service, and federal and state hospitals not only led to massive retrenchments of workers but also raised social costs and prices of commodities beyond the reach of the generality of the people.

If increasing hardship was the "sacrifice" the citizens had to make to salvage the economy, there was unfortunately too little to show for it. Foreign capital did not flow in as was hoped (instead the deregulated monetary system enabled capital flight); non-oil exports remained insignificant; external and internal debts and debt servicing repayments continued to mount: total external debt was estimated at 27 billion USD in 1987 and over 30 billion USD in 1990 while, in 1987, debt servicing repayment was 74 per cent of expected export earnings; according to Fadahunsi (1993:43), although at 1984 constant factor cost the economy recorded a growth rate of 1.8 per cent in $1987,4.16$ per cent in 1988 and 3.92 per cent in 1989, "when account is taken of the population growth rates averaging about 3 per cent per annum and annual inflation rates of between 40 and 50 per cent, growth rates since the introduction of SAP and the massive devaluation of the Naira will be found to be actually negative in real terms"; thus, per capita income rose only by about 2 per cent in Naira terms from 778 in 1985 to 175 in 1988 and 108 in 1989; the same trend was true of balance of payments figures which showed remarkable recovery in Naira terms, from -784.1 million Naira in 1986 and -2294.1 million in 1988 to +9803.6 million in 1989; privatization and commercialization did not make the enterprises more efficient or profitable in part because government was reluctant to give up control; industries continued to operate at very low capacities; huge deficits continued to mar budgetary performance; unemployment kept rising and purchasing power diminished; inflation was running at over 70 per cent, though official estimates put it at 24 per cent average, and even indicated drastic reductions from 54.5 and 
50.4 per cent in 1988 and 1989 respectively to 7.4 and 13 per cent for 1990 and 1991 respectively; etc. The only component of SAP that appeared to "work well" was devaluation which wreaked havoc on the entire domestic economy, but which the IMF, World Bank and other international financial institutions hailed. Thus, while the people suffered, the Babangida administration received commendations from these institutions and western scholars for making a good job of SAP. Thus, Babangida himself considered to be the major achievement of SAP, the increasing international understanding and support it had engendered which enabled the country to negotiate better debt rescheduling conditions and put it in a better position to meet its internal and external debt obligations (Newswatch (Lagos), 3 April 1989, p.35). These, of course, were closer to the real objectives of SAP from the point of view of the Bretton Woods institutions.

With such a balance sheet, it is not surprising that assessments of economic performance under SAP have been highly critical and negative. Even manufacturers, farmers and small-scale entrepreneurs who, as producers of "tradeables" rather than "non-tradeables", were supposed to be beneficiaries of SAP, were quite vocal in calling for its termination. This is not to suggest that SAP did not have its supporters and beneficiaries. As scholars who have been concerned with discovering the "winners" and "losers" of SAP tell us, there were many winners: the banks, financial institutions and parallel market operators who made huge profits from foreign exchange speculation, higher interest rates and other monetary transactions (in fact by 1993 there were scores of new commercial and merchant banks, community banks, 'finance houses', mortgage banks and bureaux de change) ${ }^{7}$; the multinational firms which benefited from devaluation and were able to repatriate huge surpluses; Asian-mostly Indian and Lebanese businessmen who were able to re-enter businesses the indigenization decree had barred them from; importers of used cars from Europe and some exporters who included cocoa exporters at the initial stage; and government officials, new patrons and clients of the president who had more money to enrich themselves with and new institutions to prebendalize. Rural farmers who were supposed to be major beneficiaries benefited very little, with the probable exception of cocoa farmers who enjoyed an initial boom due to the over-invoicing activities of exporters (mostly Asians and other foreigners) who cashed in on the situation to repatriate huge sums of money overseas. But whatever initial gains cocoa farmers and other farmers made were wiped out by inflation and high production costs:

It is true that, following the introduction of SAP and the devaluation 
of the Naira, the prices of some agricultural crops rose as did initially, the incomes of farmers. But once the inflationary consequences of devaluation started to catch up with the cost of farm inputs and labour in a context of subsidy withdrawal on tractor hiring, seeds and fertilizer, the farmers began to experience a diminishing income. The costs of other non-farm goods and services also turned the terms of trade against the rural producers (Fadahunsi, 1993:48; for a comparative analysis of the impact of SAP on farmers, see Duncan and Howell, 1992; and Ogbu, 1991).

The vast majority of the people were losers. The entire period of the SAP regime witnessed an unprecedented level of opposition and antigovernment (appropriately called anti-SAP) riots, strikes and demonstrations all over the country by students, labour and professional unions, women's organizations, and other organized groups. Although the democratic transition process, the rising profile of civil society opposition in other developing countries, and other developments in the global system had a lot to do with the stirring of the civil society, most of the uprisings were protests against hardships and specific aspects of SAP, particularly the removal of so-called subsidies on petroleum products. The response of government to the ground swell of opposition was twofold. On the one hand, it stepped up repression of opposition elements, employing armed soldiers to put down demonstrations and detaining and harassing leaders of organized groups. On the other hand, largely because repression was not able to quieten the people, especially the urban masses, and give it badly needed support, several palliative measures were introduced. A National Directorate of Employment (NDE) was created to generate private and informal sector employment for school leavers and graduates while extra-budgetary funds were allocated to state governments to create more jobs; the People's Bank was established to provide loans on soft terms to informal sector entrepreneurs, and communities were mobilized to establish community banks to generate and harness local capital; an urban masstransit system was introduced, and the conditions for importing mostly used cars and spare parts were relaxed to improve public transportation; after the wage freeze was removed in 1988, higher salaries and allowances were negotiated with different categories of workers; a National Commission for women was created to address women's issues, and the Better Life Programme, a neocorporatist initiative of the president's wife was adopted as a channel for uplifting rural conditions, etc. These measures did not work as expected in part because, even if their implementation had been efficient and honest which was not the case, the devastating consequences of SAP were much too complex to 
be dealt with by simple palliatives.

Several reasons have been advanced to explain the failure of SAP or rather its bad management, as there seems to be a belief that it could have turned the economy round if it had been handled with the discipline, honesty and competence required (see Faruqee, 1994). The reasons that have been given include the continued low oil prices in the world market, the fiscal indiscipline of government and brazen corruption of its officials, the deployment of resources to ensure the survival of government in the face of mounting opposition, the lack of bureaucratic and management skills required to implement structural adjustment, and the dissipation of energy and focus caused by problems arising from the truncated political transition programme which was being implemented simultaneously (cf. Olukoshi et al., 1994; Faruqee, 1994; Onimode, 1991). 


\section{THE IMPACT OF SAP}

As was pointed out earlier, the impact of SAP on ethnicity can only be meaningfully analysed if it is situated within the context of the overall impact of SAP on the state and society. What we did in the last section was to provide an understanding of SAP in terms of what it was meant to be: an economic regime. In this section, we shall briefly discuss the most important consequences of this regime under two major headings, transformed social terrain and the aggravated legitimacy crisis.

\section{Transformed Social Terrain}

Studies of households, of agrarian change, of changing employment profiles, and of deteriorating health care and educational standards under SAP, and of the strategies that were devised to cope with the changing times, all point to phenomenal changes in patterns of social relations. Two seemingly contradictory pulls have been identified as underlying these changes. One is the shrinking of state responsibility in the provision of public goods, and the other is the increased involvement of the state in other areas, especially rural development and efforts at reducing popular opposition. The two pulls derived from one of the major conceptual underpinnings of SAP advanced by the World Bank which is to realign the economic forces by getting the state to stop pampering the (urban) "parasites" whose relation to the state is only consummatory and instead reward and support the (rural) "real producers", i.e. those who contribute directly to foreign exchange earnings. Although the implementation of the programme did not quite work out this way in part because government found such realignment a very risky venture as is shown in the discussion of the legitimacy crisis below, it helps to explain why the greater burden of SAP fell on the urban dwellers.

The shrinking of state responsibility had far-reaching consequences especially for urban dwellers because it affected the most fundamental areas of individual and group lives: employment, fuel prices, transportation, health, education, interest rates and other monetary controls, price controls, provision of water and electricity, postal and telecommunication services, etc. To take the case of employment for instance, government is the major employer in Nigeria as in most other third world countries. Fashoyin (1993) estimates that at least 60 per cent of 
modern sector employment is by government. The reduction of the work force in government departments, agencies, and privatized or commercialized enterprises (especially large-scale employers like Nigeria Airways and Nigerian Railway Corporation which between them retrenched over 7000 workers in the 1980s and 1990s) therefore swelled the unemployment ranks; in fact Fashoyin estimates that up to one million workers were retrenched in the government sector between 1984 and 1989. This was of course in addition to the large numbers of unemployed graduates and school leavers, and workers retrenched by private sector establishments and manufacturing companies which were operating at low capacities. But the lot of those who escaped retrenchment was not really better. Salaries were irregular, and many went for several months without pay. Even when salaries were paid, they were constantly devalued by inflation and increased costs of rent, health care, education for children, transportation, food, clothing and other essential goods and services.

How did these transform the social terrain? First, there was a rapid expansion in the scale of involvement in the informal sector and agriculture which absorbed retrenched workers and the unemployed. Even those who were employed stepped up their multiple engagements or what Mustapha (1992) calls multiple modes of livelihood, a fairly old practice whereby workers, especially government workers, take on one or more informal sector side jobs (usually trading) to make ends meet. This expansion heightened the levels of competition in the informal sector. Second, there was a phenomenal increase in the number of the poor especially in the urban areas. The swelling number included some members of the so-called middle class who had all along been regarded as privileged salariats, but whose incomes lost the value they previously had, thereby turning them into poor people. Poverty opened the doors to all manner of vulnerability and manipulation by patrons in the struggle for survival. Prebendalism, criminality and corruption increased in government circles. At the other end of the spectrum, dropout, withdrawal and failure rates in schools increased (failure rate in the West African School Certificate examinations reached an unprecedented 70 per cent in 1985). The deterioration of educational standards in public schools especially at the primary and secondary levels led to a mushrooming of expensive private schools which poor parents and guardians could not afford.

Third, unaffordable costs of health care and other social services forced people into seeking affordable alternatives. In the area of health care especially, traditional medicine, long abandoned by many urban 
dwellers increased in importance. In the 1980s and 1990s, states like Oyo and the old Bendel organized traditional medicine fairs which were well received. Many people also turned to spiritualist churches and secret cults like the Reformed Ogboni Fraternity. The proliferation of secret cults in universities and other institutions of higher learning can also be explained in these terms. Fourth, as people turned more and more into themselves in the struggle to survive and make ends meet, the importance of interest-begetting identities of kinship, ethnicity, party membership, alumni association membership, ex-soldier, and so on, increased. Ethnic identities and loyalties in particular were rejuvenated by the increased emphasis on self-help development which was undertaken by the various ethnic organizations and community development associations (in most cases with the active encouragement and support of state governments), as well as the deft initiatives of ethnic entrepreneurs who cashed in on the conducive conditions to organize "hometown national days". The celebration of such national days included cultural activities, homage to traditional rulers, and the launching of development projects-building a school, hospital, post office or town hall, awarding scholarships, or constructing a road. Finally, there was greater integration between urban and rural areas. There were several reasons for this: the greater importance attached to hometown and community development by urban-based organizations, the expanded involvement of the state in rural development through agencies like the Directorate of Food, Roads, and Rural Infrastructure (DFRRI) and the Better Life Programme, the large number of retrenched workers, unemployed, and the urban poor who migrated to the villages but kept regular touch with developments in their former towns of domicile, and the increased scale of urbanizing influences to which many villages were exposed (one of these was the opening of rural branches by commercial banks under a Central Bank rural banking scheme ${ }^{8}$ and of community banks in several villages).

\section{The Aggravated Legitimacy Crisis}

Given the centrality of state policies and actions in explaining ethnicity, it goes without saying that the ways in which SAP affected the character of the state and the responses of state managers to these changes had important implications for ethnicity. One of the major consequences of SAP on the state was the aggravation of the crisis of legitimacy which, many scholars agree, is endemic to statehood in Africa (cf. Ekeh, 1975; Osaghae, 1989, 1993). Retrenchments, removal of subsidies, rising 
costs of food and other essential goods and services, and other hardships which SAP wreaked on the people were very costly to government because they led to a massive withdrawal of support which was replaced by fierce opposition. This was especially true of urban residents who, as already indicated, bore the brunt of the hardships of SAP, and manifested this in the escalation of riots, strikes and other forms of protest and opposition. The stepping up of state repression to check the increased militancy of the civil society further served to strengthen opposition. As urban dwellers have constituted the critical legitimacy constituency for the state since colonial times, the danger in losing their support cannot be overemphasized.

But SAP provided a new equation because the relocation of the attention of government to the rural constituency meant, in essence, a relocation of legitimacy. But how far could this go? Could the government afford the risk of losing urban support? Did the rural constituency offer a viable alternative? There was another important area where SAP posed a more immediate danger to the state. This was the neopatrimonial and patron-client structures of legitimacy which in general result from the Sultanic tendencies of power holderships in most African countries. (cf. Thomas M. Callaghy, 1987; Eisenstadt and Lemarchand, 1981). These structures depend on and are served by state control of economic and social processes which partly explains the rapid expansion of the public sector in the postcolonial period to the point where even the most private of matters like marriage and child upbringing were not immune to government control. Provision and control of jobs and promotions (even in the private sector), awards of scholarships and contracts, decisions on development projects including where they should be sited, and so on, provided state leaders with the only viable non-coercive mechanism (in many cases in the absence of elections) for continuing to stay on in power. With such control, they could manipulate differences among the people (divide and rule), build extensive layers of supporters (clients), and deal with opponents. The shrinking of the state which was a cardinal point of SAP was therefore a major threat to survival. Privatization, commercialization, entrenchment of market forces, and removal of import controls in particular amounted to not only depriving the leaders of government of some of their major instruments of survival but asking them to commit suicide!

These were the major ways in which SAP aggravated the legitimacy crisis. How did the government respond? First it stepped up its authoritarian character; indeed, the resurgence of authoritarian regimes and the stultification of democracy all over Africa has been attributed lar- 
gely to SAP (cf. Bangura and Gibbon, 1992; Beckman, 1992). But the persistence, scale and diversity of riots and demonstrations in Nigeria clearly overstretched the coercive capacity of government and, in any case, it was clear that repression alone could not solve the problem. This led to the introduction of palliatives and other hardship-reducing measures which we outlined earlier. The government also took the opportunity offered by SAP to attempt to strengthen the rural legitimacy constituency, as this 'newfound' constituency promised a useful complement or counterbalance to the inherently risky urban constituency. The forays into rural development which were coordinated by DFRRI and the local governments which were given more administrative powers, were mainly to create an enabling environment for agricultural production (development of infrastructures). But through community development efforts undertaken by various associations under government mobilization and support, the government was able to strengthen the face of its "benevolence" to garner more support (Osaghae, 1993). These ventures also provided new avenues for building patronage structures. To consolidate its reach-out and mobilize support among different categories of people-urban dwellers, rural dwellers, élites, farmers, and so on, the government relied on a social mobilization scheme whose objectives were "mass mobilization for economic recovery and social justice" (MAMSER), for which purpose a special directorate was established.

While it could manage to combine repression with palliatives and intensified benevolence towards the rural communities, the reduction of its neopatrimonial and patronage instrumentalities was a bitter pill the Babangida administration refused to swallow, and this has been identified as one of the main reasons for the failure to implement SAP properly (Faruqee, 1994). Thus, divestiture of its shares from lucrative enterprises such as commercial banks was negligible, and it continued to exert even more serious control over commercialized agencies like the Nigerian National Petroleum Corporation (through which it manages its equity in the various multinational oil companies), Nigerian Ports plc, and Nigeria Airways. But even as it managed to privatize enterprises which did not mean too much in terms of patronage (hotels, flour mills, textiles, and some insurance companies), the government created an unprecedented number of directorates and agencies most of which were directly administered by the presidency.

So at a time government was supposed to be shrinking, the country was saturated with the highest number of special and extra-governmental departments ever. The desperation for survival also partly accoun- 
ted for the profligate extra-budgetary expenditures which kept budgetary deficits at very high levels. These expenditures went into special projects like the Better Life Programme, social mobilization, and donations to sundry organizations (professional associations, labour unions, women's groups, research bodies and non-governmental organizations). Large sums were also expended on supporting community and local level development projects and buying the support of notable traditional and political élites. The creation of new states and local governments over which there were strong lobbies and "hegemonial exchanges" (Rothchild, 1986) also became another strong weapon of neopatrimonialism. In the process of doing all this, of course, existing patronages were strengthened and new ones were created especially at the local level. 


\section{SAP AND ETHNICITY}

We now come to the crux of this study. Following the modified before and after approach adopted for this study, we shall, as a backdrop, first examine the situation of ethnicity before SAP. This will help to bring out in bold relief, the impact of SAP on ethnicity.

\section{Ethnicity Before SAP}

Although ethnicity is a historically cumulative phenomenon, there is need to specify the pre-SAP period of reference here, especially since as we said earlier, the period of economic recession that led up to SAP and that of SAP itself should be regarded as part and parcel of the same regime. The pre-SAP period then would be that between independence in 1960 and 1978, with greater emphasis on the post civil war period. Obviously, it would be an uphill task to attempt to summarize the complex forms of ethnicity in this period in a short section like this, with the diverse contexts and factors that shaped the phenomenon during the period-civilian and military administrations, civil war, oil boom, etc. Fortunately, these complex forms have been well covered in the literature (cf. Nnoli, 1978; Otite, 1990 and Osaghae, 1990). What we shall do then is to briefly highlight the main aspects of ethnicity during the period. They are as follows:

1. Ethnicity was largely macro rather than micro. The regional politics of the First Republic set the pace for bloc politics which carried on through to the civil war. It was only after the war when the new states which had been created to replace the regions were consolidated that bloc politics began to disaggregate over issues like creation of more states, revenue allocation, representativeness of government institutions, and power sharing. But regionalism remained a critical component of the ethnic action set. Religion (Christian/Muslim cleavages) also reinforced these aggregative and disaggregative ethnic cleavages especially after the sharia question polarized the Constitution Drafting Committee and Constituent Assembly which met between 1975 and 1978. The main antagonists were the Muslim/ Hausa/Fulani core-North on the one hand, and the Christian South/ Middle Belt minorities. One issue which dominated the ethnic landscape and kept bloc politics alive was the fear of domination-of northern political domination by Southern leaders, of Southern 
domination of the economy and bureaucracy by Northerners, and of majority domination by minority groups. These fears created a lot of tension and anxiety, and conditioned political relations during the period. Efforts to deal with these problems included the creation of new states, changes in the structure of revenue allocation, the introduction of the quota system and eventually the federal character principle, all of which had the demonstrable effect of further encouraging and legitimizing ethnic demands.

2. At the interpersonal level, the major measure of ethnic consciousness was the amount of importance individuals attached to membership of ethnic unions which are mostly urban-based. Compared to the devotion of the vast majority of urban dwellers who were mostly first generation migrants from rural areas to these unions in the 1950s and early 1960s during which these associations mobilized support for political parties and functioned as "alternative states", the importance of these unions in the lives of individual members went through a recession in the 1970s (cf. Barnes and Peil, 1977; Peil, 1991). The ban placed on tribal unions in 1966, the absence of party and mobilizational politics under thirteen continuous years of military rule, and the active encouragement of cross-ethnic linkages and integration by the successive administrations are some reasons for this development. But perhaps the most important reason was the rapid economic expansion and buoyancy which followed the oil boom of the mid-seventies. With more jobs, wage increases (notably the windfall that was the Udoji commission increases of 1972), virtually free education and affordable health care, and enough money to pay for imported food and other commodities, there was a considerable improvement in standards of living, and relief from the pressures and insecurities which normally heighten ethnic tensions and anxieties. This did not of course mean that the ethnic strategy was no longer employed as it continued to feature in public service matters, admissions into government educational institutions, student elections, trade union activities and so on, but it was the élites and leaders of the ethnic unions who mostly propagated it and reaped its benefits. The educated elite whom the Vice Chancellor of the University of Ibadan accused in 1965 of being "the worst pedlars of tribalism" was quite notable in this regard.

3. Ethnicity within the pre-SAP period was mainly public sector ethnicity. This was due largely to the tremendous expansion in the scope of responsibilities assumed by government especially at the federal level following the oil boom. The takeover of major functions 
belonging to the state governments (including the running of universities) by the federal government and the steady erosion of state powers and their subsequent financial and administrative subordination to the federal government, establishment of more state-owned enterprises and public corporations, expansion of the bureaucracy, and the phenomenal increase in the volume of development projects initiated and executed by government (see the Second and Third National Development Plans), all heightened concern over power holdership in the centre. This was the origin of the proverbial sharing of the national cake which encouraged demands for new states, heightened disagreements over resource allocation, and necessitated the adoption of distributive or sharing formulas. In federal government schools and colleges, as well as public service, the quota system which had first been applied to recruitment into lower ranks of the army in 1958 and the officer cadre in 1962 was increasingly used in the 1970s, while efforts were made to redress socioeconomic imbalances especially those in educational advancement between different parts of the country. From 1975 when the transition to civilian rule began in earnest with the inauguration of a Constitution Drafting Committee (CDC), the question of how to prevent the domination of political power by people from one or a few sections of the country became a key issue. This was the background to the introduction of the federal character principle according to which the composition of the federal government and its agencies is required to reflect the federal character of Nigeria (for the origins, application and problems of the principle, see Ekeh and Osaghae, 1989; Osaghae, 1988).

But ethnicity was not entirely a public sector phenomenon. It also thrived in the private sector where competition for jobs, contracts, and other benefits was rife and often required "political connections" especially in multinational corporations like UAC, Shell-BP and other oil companies which were either partly controlled by the state through equity shares or had close links with state officials and politicians. But it was the promulgation of the indigenization decree in 1972 and the subsequent attempt to ensure that Nigerians themselves controlled the commanding heights of the national economy that intensified ethnic considerations in the private sector (indigenization actually began on a lower scale in the First Republic when multinationals like the United African Company were barred from retail trade which was to be run exclusively by Nigerians, but this measure did not quite succeed). The indigenization regime which 
involved the takeover of nearly 2000 companies by Nigerians was seen as the economic equivalent of contestation for political power. Consequently, indigenization brought elements of public sector ethnicity_-"Northernization", "Yorubanization", "quota system", and "federal character" -into the structure of ownership of banks, oil companies and other major firms in which the federal and state governments acquired controlling shares "in trust" for the people. Of course the foray into the private sector was a big boost to the patronage available to the political leadership, and it was well utilized to oil the neopatrimonial machinery.

4. Ethnicity was largely an urban phenomenon, notwithstanding the intricate rural-urban networks that linked city dwellers with their kith and kin in the countryside. The relative neglect of rural development by successive administrations, the virtual disengagement of most rural dwellers from the state, and their isolation from the modern economy shielded the rural areas from acute ethnic consciousness except at election times when politicians mobilized such consciousness. Much of the ethnicity that existed at the rural level was cultural, and involved cultural and religious practices and loyalty to traditional rulers. It was also closely tied to the activities of ethnic and cultural organizations which although urban-based made the hometown and countryside the focus of their self-help development activities. These organizations built schools, hospitals and recreation centres and awarded scholarships and these activities were mostly inspired by the competitive impulse not to be outdone by neighbouring communities in the level of modernization. It should be emphasized that these initiatives had little direct support from managers of the state, though some state governments created community development agencies and allocated funds and technical assistance. But as rural areas came under more urbanizing influences and state penetration, such as population movements and migration of "strangers" to the village or the siting of a government agency or institution there, ethnic tensions and agitations tended to rise.

5. The prevalent perception of ethnicity during this period, especially after the crisis of the First Republic and the civil war, was negative. "Tribalism" as it was more popularly called was regarded as evil, and "tribalists" were regarded as enemies of progress. Aptly capturing these perceptions, Ekeh (1990) has written:

(Ethnicity refers to) obnoxious modes of behaviour which threaten and endanger normal coexistence among persons from different ethnic groups. As used by Africans, tribalism in post-colonial Africa 
refers to abhorrence for the abuse of common opportunities and public goods...through manifestation of undue preferences for persons of one's own ethnic grouping... In this meaning, tribalism and tribalists are seen as evil forces in Africa which governments, trade unions, student organizations and newspapers feel compelled to fight.

With such perceptions, the emphasis, especially by military regimes was on discouraging ethnicity which was held responsible for the collapse of the First Republic and the political problems of the country. Thus, to cite some examples, the short-lived Ironsi administration proscribed the tribal unions, in creating more states in 1976 the Mohammed administration decided that states should no longer bear names which have regional or ethnic connotations to wipe out ethnic consciousness, and the makers of the 1979 constitution introduced measures which aimed at preventing the emergence of ethno-regional parties and ethnic voting. The negative perception of ethnicity made it something to be ashamed of, and this contributed in no small measure to making it unpopular with the vast majority of ordinary people. But this did not stop ethnicity from thriving, especially at the inter- and intra-group levels which as we have said underlay the problems of creation of states, revenue allocation, and power sharing amongst others. While the élites reaped the material benefits from all this, the military leaders exploited the differences therefrom to strengthen their hold on power. Interventions by the state and responses to ethnic demands (creation of more states and introduction of the federal character principle especially) not only awakened latent ethnic tensions and conflicts, but actually encouraged them.

\section{The Impact of SAP on Ethnicity}

By the very nature of economic scarcities, deprivations and hardships it entailed, as well as the intensification of competition amongst individuals and groups for jobs, resources, and political power these engendered, there is agreement among scholars that SAP heightened ethnic tensions and anxieties (cf. Adekanye, 1994; Mkandawire, 1994; ACARTSOD, 1990). These tensions and anxieties manifested themselves in different but related ways. The most politically significant of these was contestation for state power largely because, as is very well known, the state is the major means of economic and social reproduction in Nigeria (as indeed it is in most third world countries). Although one of the objectives of SAP, as an instrument of global and national capitalism, was to change this "anomaly" by entrenching market for- 
ces, the state, as we saw earlier, was not only unwilling to divest itself of its reproductive role, the aggravation of the legitimacy crisis actually led it to expand that role. This generated a fierce struggle among members of the dependent political class and increased anxiety over who controlled the state. The controversies and sectional wranglings that attended the privatization programme were closely related to this. The tensions, anxieties and intensified competition and conflicts were also manifested in different ways at the interpersonal, intra-group and inter-group levels, as we show below. What was particularly remarkable at these levels was a sharpening of ethnic consciousness, of 'us' and 'them'. The desperation to survive and make ends meet, the resultant heightening of corruption, as well as the intensification of conflicts between and amongst classes, especially amongst members of the privileged classes, all helped to sharpen this consciousness.

As we pointed out at the beginning of this study, these changes cannot be attributed solely to SAP. For example, the sharpening of ethnic consciousness was accentuated by other processes and events. There was for example an upsurge in fundamentalist Muslim activities in several parts of the North (whose origins partly lay in the global upsurge of fundamentalist Muslim activities) which rekindled minority opposition to Hausa/Fulani domination and resulted in violent conflicts. In major cities like Kano, Zaria, Kaduna and Bauchi, the so-called religious riots which were reminiscent of the 1966 pogroms which involved the massacre of several hundred Igbos and Easterners, pitched Muslim Hausas against Southerners, mainly Igbos and Yorubas who lived in sabon gari (strangers quarters).

At the national level, Muslim-Christian division was reinforced by policies and actions of the federal government such as Nigeria's membership of the Organization of Islamic Conference (OIC) which was announced in 1986, which suggested a desecularization and possible Islamization of the country. The politicization of religion reinforced ethnic and regional cleavages. Then there was the democratic transition programme which reinforced the contradictions of SAP, provided the context for open contestation for state power, and has been identified as being very conducive to the articulation of ethnic grievances and struggles, especially in countries like Nigeria where prolonged authoritarian rule suppressed them (Osaghae, 1992). But, as we have said, these factors exacerbated or gave vent to extant tensions, anxieties, grievances and conflicts (latent and manifest) which were deep-rooted and had gathered momentum during the period of economic recession which preceded (or, as some would say, necessitated) SAP. They are 
therefore contributory or reinforcing factors and do not supplant the primacy of economic factors in explaining the changing landscape of ethnicity that followed the SAP regime.

\section{Micro Ethnicity}

The impact of the SAP regime on ethnicity was varied and complex. At the interpersonal level, there was a heightening of ethnic consciousness as many people fell back on their ethnic and kinship connections to secure employment or retain their jobs, to get loans or aid to begin small or medium scale businesses, or even to get money for food, buy drugs, pay school fees, and meet other essential needs. The heightening of ethnic consciousness and the interest-begotten uses to which it was put was clearly manifested in the rising profiles of ethnic associations in towns and cities. Not only was there an upsurge in the membership of these associations and enthusiasm for their organization (as there was in old boys/alumni associations, secret cults like the Reformed Ogboni Fraternity, churches, Muslim bodies and other religious organizations, as well as influential social clubs and professional associations), there was also a rapid expansion in their number, variety and purposes.

Studies of the changing character of urban-based ethnic organizations carried out by this author in Kano, Ibadan, Lagos, and Benin city in 1990 and 1993 showed these and other interesting developments (Osaghae, 1990, 1994b). Some of the findings of these studies may be briefly highlighted. First, there was a sharp rise in the membership of young men and women, especially fresh university graduates, whom leaders of ethnic associations always accused of lukewarmness towards the activities of these associations in the past. The growing interest of youths was also largely responsible for the increased number of ethnic social clubs, as those who found it difficult to join conservative ethnic associations organized more modern and status-enhancing social and youth organizations. Second, many ethnic organizations, especially the older and more inclusive ones were increasingly torn apart by class and status differences and divergent interests which produced rival elite and non-elite organizations. In general, the elite organizations were more interested in competing for government positions and other privileges in the name of the ethnic group, while the non-elite ones focused more on mutual self-help and cultural activities, but there was always rivalry over which side represented the true interests of the ethnic group.

Thirdly, in addition to the 'conventional' ethnic organizations-the 'Sunday-Sunday' associations, clan, hometown, divisional, state, 
women's, and all-inclusive ethnic and cultural organizations-there were other not so conventional ones whose importance increased under SAP. The most notable of these were establishment or workplace ethnic organizations which proliferated IN government ministries, departments, and agencies, including the armed forces and universities, and major private enterprises. Establishment ethnic associations protected the interests of members of the ethnic groups in matters of appointment, promotion, and discipline and played crucial roles in processes of selecting chief executives and departmental heads as well as in electing labour union executives. There were also what I have referred to as migrant ethnic empires organized mainly by the Igbos and Yorubas in most Northern capital cities. These empires, which closely resembled the "retribalized" political organization of the Hausa community in Sabo-Ibadan studied by Cohen (1969) involved the recreation of traditional structures which had the Eze in the case of the Igbos and the Oba for Yorubas as head.

The emergence of these traditional forms which existed alongside hometown and central ethnic associations was influenced by the feudal and traditional settings of cities like Kano, Katsina and Sokoto and the belief that traditional structures are more effective mechanisms for furthering constitutive interests in the host community (which included greater integration into and acceptance by the host community). This "retribalization" entailed a cultural reawakening which particularly helped to ensure that Igbos and Yorubas who had become 'settlers' rather than 'migrants' did not lose their ethnic identities and loyalties. Finally, ethnic organizations were very active in promoting and protecting the interests of members, especially needy ones like the unemployed and retrenched, the sick and the bereaved. The Eze-Igbo and other leaders of the Igbo Community Association in Kano for example established a social welfare scheme in 1993 to help members who were in need. In Benin city, many social clubs and 'progressive' unions even went to the extent of sponsoring members overseas as emigration abroad became a popular way of coping with the hardships. These were the kinds of services which endeared these associations to desperate and destabilized urban dwellers. They were of course not new but individuals found in them in the turbulent sea of SAP, a rock to hold on to.

The temptation to exaggerate the importance of these associations for individuals should however be resisted. The empirical evidence shows for example that many members continued to default in the payment of membership fees, that attendance at meetings was often poor, and that a substantial part of these meetings was spent on settling dis- 
putes amongst members. But these do not detract from the fact that many urban dwellers came to (in some cases finally) recognize the importance of ethnic connections for pursuing their interests, and that this led them to greater involvement in ethnic associations. But it was not only for this instrumentalist reason that ethnic associations attracted greater interest. There was also the increased involvement of these organizations in different forms of development, and the efforts of their leaders to convert more people to worship the tribal god. The latter took the form of the celebration of annual ethnic or hometown "national days". These celebrations, as pointed out earlier, involved cultural festivities, rituals, and paying homage to traditional rulers, as well as the launching of one or more development projects. It was however in their involvement in development projects that ethnic organizations particularly had a higher profile. This was due partly to the encouragement given by the federal and state governments to self-reliant efforts especially in the area of rural development, and partly a response to the retrenchment of the state in key areas of societal life, including the protection of lives and public safety.

The crucial roles played by ethnic associations in the development of their home areas is well established in the literature (cf. Barkan et al., 1991). These roles which include creating local capital and functioning as "shadow" or "alternative" states in the provision of amenities and social services, became more important under SAP. Much of the engagement was in the traditional hometown concerns-building or rehabilitation of schools, hospitals, markets, town halls, postal agencies, and in some cases police stations, provision of school materials, scholarships and essential drugs to hospitals, construction of roads, etc., in the countryside-for which special appeal funds, similar to the "Harambees" in Kenya, were launched (see Barkan, 1994 for a good comparison of self-help processes in Nigeria and Kenya). These initiatives were encouraged and actively supported by state and local governments. In the former Bendel state for example, between 1985 and 1988, there was a fierce competition amongst communities to raise funds for special development projects. The impetus for this competition was the state government's announcement that the provision of services and amenities by the state government, as well as the distribution of its development projects would be based on the levels of self-help development in the localities. This was a clever way of abandoning the responsibility of the government to the communities, but it galvanized ethnic organizations and, as we argued earlier, created a new patronage weapon. State governments themselves also launched appeal funds for special projects at which ethnic associations seeking one favour or 
another for their constituents donated generously. For example, the Kano state government launched an educational foundation fund in 1990 to which the Igbo Community Association, the Yoruba Community and other strangers' ethnic associations were major donors. It was hoped that such a gesture would get the state government to pay attention to the neglected Sabon gari.

There were however more direct ways in which the federal government mobilized or co-opted ethnic associations to become more involved in development, especially at the local level. The rural development and local investment components of SAP provided the context for this. Communities which did not already have social organizations were encouraged to form Community Development Associations (CDAs) which were made the fulcrum of the new form of grassroots development. The Directorate of Food, Roads and Rural Infrastructure (DFRRI) which was created in 1986 to alleviate rural poverty, uplift rural areas to stem the tide of rural-urban migration, and develop the enabling environment for these areas to contribute optimally to the economic development of the country, and the World Bank assisted Agricultural Development Projects (ADPs) were supposed to work closely with these groups in the determination and execution of projects which included the sinking of boreholes, rural electrification and construction of earth roads (for DFRRI), introduction of improved seedlings, fertilizers and modern farming techniques (ADP). The Directorate of Social Mobilization which easily became the propaganda arm of government also made the CDAs the basic unit of the MAMSER programme in the rural areas. Finally, the attempt at generating local capital through the community banks which were introduced in 1988 also had the CDAs as the main vehicle.

The concerted opening up of rural areas through these processes (which also included the establishment of more rural branches of commercial banks, and other mobilization schemes like the Better Life Programme) awakened nascent ethnic consciousness in the rural areas and CDAs became, in association with other ethnic associations, the instruments of ethnic (mainly intra-group and particularistic) competitions and conflicts. DFRRI projects and the siting of community banks became major objects of competition and dispute between communities. The ethnic landscape in rural areas was affected by these processes in other important ways. New forms of accumulation brought new men of power, strengthened extant power relations especially between traditional rulers and their subjects, and expanded the patronage structures of the state. The real beneficiaries from rural development then were wealthy sons and daughters of the soil (most of whom were based in 
the urban areas) who established community banks in the name of their communities, the leaders of the CDAs who, as new entrepreneurs of ethnic interests got an opportunity to enrich themselves, traditional rulers who were able to accumulate more wealth, strengthen their control over the ethnic constituency, and improve their client relationships with the state, and DFRRI and local government officials.

The other major beneficiary was the state whose managers, as was pointed out earlier, found a useful basis for dealing with the aggravated legitimacy crisis. What did these mean for ethnicity in the rural areas? First it meant the transformation of intra-group ethnic awareness into ethnic consciousness for most rural dwellers. The competition that followed the new opportunities and the development of new patron-client relationships reinforced this transformations. Second, it meant the extension of privileges for the local bourgeoisie and ethnic entrepreneurs who not only had new ethnic constituencies but also greater access to state resources and patronage. Third, for the state it meant wider latitude for manipulating differences, building new support constituencies and responding to the legitimacy crisis. The strengthening of local governments as an autonomous tier of the federal grid as part of the democratic transition programme, and the subsequent clamour for and creation of new local government areas were a big boost to these emergent tendencies.

It would be wrong to conclude that the activities of CDAs and other more specifically ethnic associations were altogether negative. For one thing, the mostly urban based ethnic associations and governmentinspired CDAs were not the only actors in self-reliant community development. There were also the age grade groups, village councils and women's organizations which have traditionally been the agencies of community development for the vast majority of rural dwellers. It is probably right to say that it was the neocorporatist and patronage uses to which the managers of the state sought to put these institutions that engendered the negative tendencies. But even so, the generation of local capital through community banks was a positive step. In the case of ethnic associations, the social welfare functions performed for needy members, especially the provision of soft loans and aid, the establishment of cottage industries in the rural areas and efforts at providing services which the state was no longer able to do were positive rather than negative.

Indeed, where the involvement of ethnic associations and CDAs in the development process was based on self-help efforts, and did not involve the state, the result was, for the most part, what we have called 
positive ethnicity. In some cases, government only came in to help complete the projects through technical assistance or grants in aid (for an empirical analysis of self-help projects and patterns of government involvement, see Idode, 1981-82). Atte (1986:148) has summarized the positive contributions of community based social organizations to rural development through self-help efforts as including the building of feeder roads, bridges and markets, establishment of schools and colleges, provision of health care services, and raising the consciousness of the people about their latent potentials and enhancing individual and community self-esteem and self-reliance. The point is that under SAP, these engagements became more pronounced and the hijacking of the initiatives by agencies of the state and ethnic entrepreneurs did not detract from the entrenched self-help orientations. This was true for the masses of the people for whom neglect by the state has historically made selfhelp development a way of life.

But positive ethnicity was not only to be found in the rural areas; it also existed in the urban areas where ethnic associations have long been involved in different areas of community development. Powerful ethnic organizations have been known to establish schools in the past (a notable example was the Igbo State Union in Kano which ran a secondary school in 1964-66), to be involved in resolving disputes between members of their ethnic groups and members of host and other ethnic groups, and to supplement government's efforts in providing amenities and social services singly or in collaboration with other ethnic associations and the host community. These activities were most obvious in but not restricted to cities where strangers or non-indigenes are settled in exclusive areas such as the sabon gari in many northern cities. In Kano, the roles of the Igbo Community Association (ICA) and Yoruba Community based in sabon gari, following the retrenchment of government's involvement in the provision of social services and amenities under SAP, were most notable in this regard. The ICA in particular organized to, amongst other tasks fill the potholes on sabon gari roads, to clear refuse which the local government failed to clear, and to protect lives and property through providing assistance to the police and organizing, in collaboration with the other ethnic associations, a self-protection network especially when it became obvious that the state government was doing too little to protect the inhabitants of sabon gari from the so-called religious uprisings (Albert, 1993; Osaghae, 1994).

It could be argued that these activities were a response to the historical neglect of sabon gari in the provision of services and amenities, but it cannot be denied that the almost complete stoppage of government 
involvement in the upkeep of the area and the welfare of its inhabitants under the SAP regime galvanized these associations into mobilizing doit-yourself efforts. Besides, the community development engagements of the ICA and other ethnic associations were not restricted to sabon gari. They played crucial roles for example in ensuring inter-group harmony not only amongst people of diverse ethnic backgrounds in sabon gari but between them and the host Hausa community, and contributed to the appeal funds which the state and local governments launched for different projects. In other parts of the country, the profile of ethnic associations in urban relations increased in several areas.

In the organization of the informal sector for example where there is a great deal of ethnic specialization (in Ibadan, the foreign exchange black market is monopolized by Hausas in Sabo, the spare parts trade is dominated by Igbos, the garri trade has Edo, Yoruba, and Igbo sections, the yam trade is shared between the Tiv/Idoma and Yoruba, the cattle, goat and sheep trade is dominated by the Hausas, and so on), these associations helped to reduce the tensions generated by the increased entry of people in that sector. The richer ones provided loans and credit facilities to traders (not only to their members that is), and the ownership structures of many community banks in Lagos, Ibadan, Port Harcourt and other large cities showed that these associations no longer had the hometown orientation that has always been assumed. This finding is not new as such, because ethnic associations have all the while played important roles in urban relations and development, but the changing social terrain which followed SAP made these involvements far more important. Finally, ethnic associations assisted the police in the prevention and control of crime which exploded in most cities under SAP. We have already referred to the activities of the ICA in Kano. In Lagos, Port Harcourt, Benin city, and other major cities, ethnic associations were involved in community policing programmes introduced by the police force.

\section{Macro-Ethnicity}

It was at the macro-level that the social tensions and anxieties generated by SAP were both most obvious and consequential. The diminished resources and opportunities heightened anxieties over the representativeness of government, the major allocator of resources and means of social reproduction, intensified competition for its control and patronage amongst members of the political class, and led to the increased militancy of the civil society. These all had critical ethnic dimensions and anchorage. Most notably, there was a generalization of the ethnic 
strategy and resuscitation of bloc politics of the ethno-regional kind. Even civil society organizations-trade unions, human rights organizations, professional associations, student unions, women's organizations, and so on-were not immune from this generalization of ethnicity, and some of them were converted into instruments of ethnoregional struggles for supremacy. The democratic transition programme which involved a great deal of manipulation of divisions (ethnic, religious, regional) by the Babangida regime to remain in power, and the 'traditional' patterns of ethno-regional mobilization and support by leaders of the two government imposed political parties provided a conducive context for this. The annulment of the presidential election of June 12, 1993 which was to be the last leg of the protracted "democratic transition without end" led to an intensification of tensions similar to those which preceded the civil war in 1966-67, and for a long time after that, the country was on the brink of another civil war or disintegration of the federation.

Adekanye has proposed an empirical strategy for studying the macro-ethnic consequences of SAP which perfectly accords with the theoretical premise of this study. According to him, the intensification of ethnic tensions and conflicts is determined by the extent to which SAP reinforced extant social, economic and political inequalities or created new ones. This linkage is based on the empirical fact that the implementation of SAP, as a capitalist strategy, heightens inequalities:

...just as SAP tends to increase the poverty of the very poor social groups or classes, and to impoverish people in the managerial and professional occupations other than perhaps the armed forces, while the very few rich grow even richer, so does the socioeconomic incidence of SAP vary from one political region to another, from ethnic group to ethnic group, and between different communities (Adekanye, 1994:11).

Adekanye further highlights two related factors which underlie these inequalities. These are the pre-SAP structure of control of the economy and the location of groups within the structure of power relations, "that is, whether they constitute part of the "core" ruling group(s) or are "peripheral" to them" (p.12). Those who belong to the ruling coalition are more likely to benefit from (and even to be supportive of) SAP, while the peripheral groups, whose losses and disadvantages are extended by SAP, are most likely to step up their (extant) opposition or resistance to the ruling coalition as well as to SAP itself. The situation is likely to be even more volatile in cases where the peripheralized groups are the sources of the country's wealth or control major sectors of the economy. The case of the Ogoni, from whose lands a significant 
proportion of Nigeria's oil wealth is derived, is considered below. To these may be added the perceptions of inequalities which, proponents of the relative deprivation thesis argue, are in fact more critical for political action than the inequalities themselves, and the role of the élites who mobilized group solidarity and action on this basis. These insights provide a useful background to the analysis of the ways in which SAP impacted on ethnicity at the macro-level. For this we shall focus on three cases which are illustrative of the trends: the politics of privatization, the Ogoni uprising, and the struggle to control the federal government.

\section{The Politics of Privatization}

Privatization provided another opportunity for the question of the ethnic distribution of control of the economy to be placed on the political agenda. The backdrop to this was the attempt to indigenize control of the economy in the 1970s and 1980s which led to lopsided and uneven controls of different sectors by sections of the country. The indigenization exercise was believed to have favoured the Westerners, especially the Yorubas who, it was said, used their bureaucratic and technocratic advantages to take over control of most sectors of the economy, including the manufacturing sector, the banking and finance sector, the oil sector, and the service sector. The chief antagonists of the Westerners were the Northern élites and the Easterners/Igbos. The Igbos in particular regarded the timing of the indigenization exercise as unfair because, having been ravaged by the civil war, they were not in a position to compete with the others for control of the economy. Given such a background and the larger context of diminishing resources, privatization was bound to generate a lot of tension.

The federal government itself recognized the political nature of what ought to have been an economic programme. In fact, the government saw privatization as an opportunity to redress regional imbalances in the location of industries which are concentrated in Lagos, Kano and Rivers states while states like Adamawa, Yobe, and Taraba have only state government owned industries. Thus, tax concessions were granted to manufacturers who invested in industrially-disadvantaged states. For example, new companies established in the old Gongola state were entitled to 100 per cent capital depreciation allowance (West Africa, 17 July 1991:1070). In the guidelines for privatization, "interregional, interpersonal and interstate distribution (of shares) was to) be considered" (Yahaya, 1993:19). To this end, the privatization and commercialization decree stated that all interest groups and associations-trade 
unions, women's organizations, universities, community associations, state investment agencies, and so on,-would be encouraged to buy shares. Equity was also to be emphasized in selling shares to ensure that the enterprises were not bought by only a few "money bags".

But these did not prevent grievances by some sections of the country. In particular, chambers of commerce in some northern states and political leaders who were eager to check what has historically been perceived as Southern control of the economy complained that only a few people from these states could afford to or were willing to buy shares. State governments responded to such complaints by mounting media campaigns to explain to the people the (political) importance of the privatization programme, and in some cases, arranging loans for civil servants and other indigenes to buy shares. The military governor of Kano state chastised indigenes of the state for refusing to buy shares: "While states like Anambra, Bendel, Imo and Oyo (all in the South) have each applied for shares worth over 2 million Naira in the Nigerian Flour Mill, Kano's was a little over half a million Naira. Yet we claim to be next to Lagos (in commercial ranking) which has applied for shares worth over 14 million Naira" (cited in Ate, 1991:168). At one stage, Hamza Zayyad, the chairman of the TCPC who is himself a Northerner called on Northerners to rise up to the challenges and opportunities offered by privatization to catch up with the rest of the country (see Daily Times, 27 November 1989). In the South, although state governments did not become involved, the privatization programme was not without anxieties, especially on the part of those who saw the programme as an opportunity for the north to use its dominance in power relations to also capture the economy. This was the perception that led to the vehement opposition of traditional rulers, businessmen and women, political leaders and government officials in the Yoruba states of Ogun, Ondo and the old Oyo, joint owners of O'dua Investment Company Limited to the agreement which gave controlling (60 per cent) shares in Cocoa Industries Limited, a subsidiary of O'dua, to Emerald Packaging Company owned by a Hausa from Katsina state, Alhaji Garba Lawal. Although there were also misgivings about the manner in which the agreement was made and the fact that the shares were undervalued, the major consideration was that the company should have been sold to an indigene of one of the three states rather than an "exploiter" from the north (see Newswatch, 11 February 1991:26-28). 


\section{The Ogoni Uprising}

The Ogoni, a minority ethnic group in Rivers state, rose up in arms as it were, to demand political autonomy in the federation, an end to their marginalization from political power in the country, reparations from the federal government and oil companies for environmental degradation and decimation of their sources of livelihood as a result of oil exploration and refining activities on their lands, and changes in the structure of revenue allocation in the federation. These demands were contained in the Ogoni Bill of Rights which leaders of the Movement for the Survival of Ogoni People (MOSOP) and traditional rulers of the various Ogoni clans submitted to the federal military government in 1990 (for the full text of the bill, see Saro-Wiwa, 1992:93-100). What followed the bill to which the federal government failed to respond was a period of uprising between 1990 and 1993. The uprising took the form of propaganda in the local and foreign media, appeals for international assistance through the presentation of the Ogoni case at United Nations meetings and other international forums, mass action, demonstrations, petitions to oil companies, boycott of the presidential election, and attempts to prevent oil companies from operating in Ogoniland.

Later, there were clashes with soldiers who were deployed by the government ostensibly to protect oil rigs and other installations, but whom the people accused of repression and genocide. Several Ogonis were killed and their property destroyed in these clashes. Violent conflicts also broke out between the Ogonis and two other neighbouring minority groups, the Andoni and the Okrika. The reasons for the conflicts are highly controversial, and many Ogonis who claim to have no major disputes with the other groups believe they were fomented by the federal and Rivers state governments as part of the repression process. However, issues of rights to land, fishing rights, disputes over oil well locations and other local matters underlie the violent conflicts which came to involve virtually all the ethnic groups in Rivers state (Kalabari, Ijaw, Ikwerre, Nembe, and others). As part of the repression of the Ogoni uprising, Saro-Wiwa and other MOSOP leaders were constantly harassed, detained and put on trial at different times on charges of treason, murder, and disturbance of public peace (for an analysis of the Ogoni uprising, see Osaghae, forthcoming).

The Ogoni uprising can be attributed to several factors, including the prolonged struggle by the Mid-Western and Niger Delta minorities to use their 'oil power' as a leverage to secure more favourable allocation of resources and end their marginalization in power relations in the 
federation which is dominated by the three major groups; the democratic transition programme which was conducive to the expression of grievances by groups, especially as through the creation of new states and local government areas and revisions of the resource allocation structure, the federal government encouraged ethnic demands; the increasing militancy of the civil society and opposition to the Babangida administration (it should be noted that there was a moderation in the confrontational strategy adopted by MOSOP after Babangida was forced out of office); the radical character of MOSOP leadership; and the favourable international climate-the emphasis on human rights, especially the rights of minorities and indigenous peoples to self-determination, environmental issues, and the support given to oppressed groups which rose up in arms. But underlying these factors were the tensions caused by economic decline, rising debts and diminishing resources. The linkage is made by Saro-Wiwa (1992:92-3) thus:

They (the Ogonis)...found that the Nigeria of which they were a part was deeply in debt in spite of the enormous resources which they had contributed to it; that it was getting deeper into debt and that the only way those debts could ever be repaid was by the exploitation of Ogoni resources, which exploitation would do even more harm to Ogoni existence.

And they knew that the only thing that could make the eighth oil producing country in the world also the thirteenth poorest was gross mismanagement by the ethnic majority who wielded power in the country. And it became obvious to them that the country was headed in a wrong direction and that something would have to be done urgently to alter their situation and the situation of the country, if all was not to be lost.

While much of this is an attempt to justify the Ogoni uprising, its linkage to SAP is well made. The Ogonis were anxious to redress their economic and political marginalization and exploitation by the ruling coalitions dominated by members of the majority groups if they were to be able to cope with the economic decline. For that matter, their struggle was not an isolated one. The upsurge in conflicts between minority groups and the dominant Hausa/Fulani in many parts of the north as well as between minority groups in Rivers state and other parts of the country had basically the same impulses and motives.

\section{The Struggle for State Power}

Diminishing resources and the deterioration of living conditions as well as the perceived reinforcement of inequalities amongst different sections of the country as a result of the implementation of SAP underlay 
the intensified struggle for state power in the period under consideration. The struggle which, as was indicated earlier, resuscitated bloc ethno-regional divisions of the 1950s and 1960s, was waged on two fronts. One was within the ruling military coalition, and the other, between and within the two political parties. With regard to intra-military struggles, there were surprisingly not too many coups or attempted coups notwithstanding persistent rumours to the contrary. Only two coup attempts were announced by the government: the General Mamman Vatsa coup which was nipped in the bud late in 1985, and the Major Gideon Orkar coup of April 1990 which was a near success. The Orkar coup showed clearly the rising ethnic propensity of military intervention and rule. The core of the coup organizers were middle-ranking and non-commissioned officers from minority groups of the Middle Belt (the historical hotbed of opposition to Hausa/Fulani hegemony in the North) and the South, particularly the oil-rich areas of old Bendel and Rivers states.

For the first time in the country, there was a coup whose objectives were stated in purely political terms: the eradication of Hausa/Fulani hegemony in the North and their virtual monopoly of political power in the federation, and giving the minority groups from whose areas the bulk of the country's oil wealth is derived and other minorities their rightful place in power relations. In the broadcast announcing the coup, seven states-Sokoto, Kano, Kaduna, Borno, Bauchi, Katsina, and

Niger-which were regarded as the bastion of perpetual Hausa/Fulani domination were to be excised from the federation. The coup failed, but its character was a clear indication of the tensions amongst officers from marginalised groups within the military. There were other manifestations of growing tensions and anxieties within and outside the military. Chief among them was the spate of agitations and acrimonies that followed the unrepresentativeness of the Armed Forces Ruling Council and the Federal Executive Council, the two highest ruling bodies, (the Hausa/Fulani complained of exclusion from the Armed Forces Ruling Council, the highest policy making organ of the Babangida administration, at the initial stages, as did the minorities of the former Bendel state, of exclusion from the executive council) and lopsided appointments of military officers to command positions, and top political offices: Chief of General Staff and later Vice President, ministers and state governors. With deteriorating economic conditions, it seemed that any group that was excluded from the top echelon of the military government had no hope of surviving the hardships of SAP. 
Under the circumstances, the competition for control of government by the politicians was also very fierce. The two-party system and the two political parties-Social Democratic Party (SDP) and National Republican Convention (NRC) - had been imposed by the federal military government to check the relapse of party politics into ethnic struggles for supremacy which was the case in the multi-party situation of the First and Second Republics. Other measures like the initial ban placed on old politicians and novel electoral systems were meant to reinforce the attempt to reduce ethnic politics. Elections into legislative assemblies and gubernatorial positions at the local and state levels, and even those into the two chambers of the National Assembly seemed to justify the undemocratic decision to impose parties as old ethnic and regional patterns of support seemed to have given way to new transgroup alliances and coalitions. But the evolving patterns fizzled out rapidly following the inexplicable decision by General Babangida (and other members of the ruling junta) to annul the presidential election of 12 June 1993 which was believed to have been won by Chief M.K.O. Abiola of the SDP.

The aftermath of that annulment saw a steady deterioration of relations amongst élites from different sections of the country. This followed the divisive interpretations that were given to the annulment of the election. The most popular of them and the one which underlay the reactions of people from the different sections of the country was that it was a deliberate design to prevent a Southerner (or Yoruba) from becoming president. This warranted the articulation and defence of sectional positions: "Northern" position, "Middle Belt" position, "Yoruba" position, "Igbo" position, "Mid-West" position, "Southern Minorities" position, and so on, though of course there were as many variations in these positions as there were groups articulating them. The political crisis which ensued provided an outlet for all the anxieties and tensions that the SAP regime had unleashed, which took the form of agitations for a restructuring of the federation and more acceptable power sharing and resource allocation systems. There were even extreme agitations for a break up of the federation or its replacement by a confederal arrangement. This was the position of the federation at the end of 1993. 


\section{CONCLUSIONS}

This study has attempted to show theoretically and empirically, the ways in which SAP impacted on ethnicity in Nigeria. SAP exacerbated ethnic tensions and conflicts at the interpersonal, intra-group and intergroup levels of social relations in part because it was an attempt to manage a deep-rooted crisis of economic decline and diminishing resources. Its major components-devaluation, removal of subsidies from social goods, rationalization of the public sector, and various monetary and fiscal measures-worsened rather than improved the economic decline because they were geared more towards satisfying the conditionalities imposed by the IMF, World Bank and Euro-American interests and reaching better understanding between the Nigerian capitalist class and its international patrons than responding to the needs and demands of the masses of the people. But it was the manner in which the managers of the state responded to the dangers to their own survival which came with the implementation of "anti-people" policies of SAP-which was discussed in terms of the aggravation of the legitimacy crisis-that proved to be more consequential for the exacerbation of ethnic tensions and conflicts. In particular, the attempts to create new legitimacy constituencies in the rural areas and to make legitimacy capital of the privatization programme as well as the strengthening of authoritarian tendencies, all heightened anxieties and conflicts over control of the state. But the impact of the SAP regime on ethnicity was not altogether negative. The retrenchment of the state from major areas of public life led to an increased profile of ethnic associations in self-help development both in the urban and rural areas. This reinforced some of the positive aspects of the involvement of these organizations - such as generation of local capital and provision of social welfare services-in the development process. 


\section{NOTES}

1. Particularly striking in this regard is the popular reference to most Northerners as "Hausa" by Southerners.

2.It will be recalled that the civil war followed an attempt by the Igbos, acting in the name of the Eastern region which had several minorities, to secede from the federation. The opposition of the minorities to secession, especially after separate states were created for them by the federal military governme$\mathrm{nt}$, led to their persecution by the Igbos during the war. Since then, relations between the Igbos and the minorities have remained strained.

3. Predominantly is used in quotes because the exact figures of Muslims and Christians are highly contested. Besides, the vast majority of so-called Muslims and Christians are only nominally so; they remain adherents of various traditional religions.

4. This is partly true because, while many people from the minority groups speak Hausa (perhaps because it is perceived as the language of political domination in the country), they remain strongly opposed to Islam which they see as the basis of domination.

5. An ethnocratic state is one which is ruled on the basis of ethnicity, especially one in which political power is dominated or monopolized by an ethnic group.

6. The situation was compounded by the oil glut which followed increased production from the new oil fields in the North Sea, Mexico and Alaska, and the slowing down of production by multinational oil corporations in the country because of what they called disincentives by the Obasanjo administration (such as the nationalization of Shell-BP in 1977).

7. To cite a few examples of huge profits declared by banks in spite of the problems of SAP: Lobi Bank, an ailing bank owned by the Benue state government, had a profit of 1.81 million Naira in 1991, up from 617,000 Naira in 1990; Rims Merchant Bank, one of the "SAP banks", i.e new banks which emerged to reap the benefits of SAP, had a profit of 12.7 million Naira in 1991; Union Bank's profit rose from 94.9 million Naira in 1989 to 97.7 million Naira in 1990; and NAL Merchant Bank recorded a profit of 50 million Naira in 1990, over 47.9 million the previous year.

8. According to records from the Central Bank, 154 rural branches were opened by commercial banks between 1986 and 1989, though the target was 300 branches. 


\section{REFERENCES}

ACARTSOD (1990) Ethnicity, Citizenship, Stability and Socio-Economic Development in Africa: Proceedings of the Regional Conference held in Tripoli, Libyan Arab Jamahiriya, 5-9 August 1989 (Tripoli: ACARTSOD)

Adekanye, J. Bayo (1994) "Structural Adjustment, Democratisation, and Rising Ethnic Tensions in Africa" (Oslo: mimeo)

Adepoju, Aderanti ed.(1993) The Impact of Structural Adjustment on the Population in Africa (Portsmouth and London: Heinemann, James Currey and UNFPA)

Ake, Claude ed. (1985) Political Economy of Nigeria (London and Lagos: Macmillan)

Albert, Isaac O. (1993) Inter-Ethnic Relations in a Nigerian City: The Historical Perspective of the Hausa-Igbo Conflicts in Kano, 1953-1991 (Ibadan: IFRA)

Albion, Adam S. and Lampe John R. (1994) Strains of Economic Transition and Ethnic Conflict: Report of a Workshop co-sponsored by the Woodrow Wilson Center and the Central European University, Prague (Washington, DC: Woodrow Wilson Center)

Ate, Bassey E. (1991) “The Political Imperative of Structural Adjustment in Nigeria” in Lual A. Deng, Markus Kostner and Crawford Young eds. Democratization and Structural Adjustment in Africa in the 1990s (Madison: African Studies Programme, University of Wisconsin)

Atte, Olawayomi D. (1986) "Overcoming Rural Underdevelopment in Nigeria: Past Approaches and an Alternative View" Quarterly Journal of Administration, Vol XX, Nos 3 and 4

Azarya, Victor and Chazan, Naomi (1987) "Disengagement from the state in Africa: Reflections on the experiences of Ghana and Guinea" Comparative Studies in Society and History, Vol 29, No 1.

Bangura, Yusuf (1991) "Overcoming Some Basic Misconceptions of the Nigerian Economic Crisis" in Adebayo O. Olukoshi, ed. Crisis and Adjustment in the Nigerian Economy (Lagos: JAD) and

Gibbon, Peter (1992) “Adjustment, Authoritarianism and Democracy in Sub-

Saharan Africa: An Introduction to Some Conceptual and Empirical Issues” in Peter Gibbon, Yusuf Bangura and Arve Ofstad eds. Authoritarianism, Democracy, and Adjustment: The Politics of Economic Reform in Africa (Uppsala: Nordiska Afrikainstitutet)

Barkan, Joel D. (1994) "Resurrecting Modernization Theory and the Emergence of Civil Society in Kenya and Nigeria" in David E. Apter and Carl G. Rosberg eds. Political Development and the New Realism in Sub-Saharan Africa (Charlottesville and London: University Press of Virginia)

, McNulty, Michael L. and Ayeni, M.A.O (1991) 'Hometown' Voluntary Associations, Local Development, and the Emergence of Civil Society in Western Nigeria” Journal of Modern African Studies, Vol 29, No 3

Barnes, Sandra T. and Peil, Margaret (1977) "Voluntary Association Membership in Five West African Cities” Urban Anthropology, Vol 6

Bayart, Jean-Francois (1993) The State in Africa: The Politics of the Belly (London and New York: Longman

Beckman, Björn (1992) “Empowerment or Repression? The World Bank and the Politics of African Adjustment" in Peter Gibbon, Yusuf Bangura and Arve Ofstad eds., Authoritarianism, Democracy, and Adjustment: The Politics of Economic Reform in Africa (Uppsala: Nordiska Afrikainstitutet) 
(1993) "Economic Reform and National Disintegration", Paper contributed to Workshop on Economic Reform in Africa's New Era of Political Liberalization”, Washington DC, April 1993

Brass, Paul R. (1985) "Ethnic Groups and the State" in his ed. Ethnic Groups and the State (London and Sydney: Croom Helm)

(1991) Ethnicity and Nationalism: Theory and Comparison (New Delhi: Sage)

Bratton, Michael (1994) "Civil Society and Political Transitions in Africa" in John W. Harbeson, Donald Rothchild and Naomi Chazan eds., Civil Society and the State in Africa (Boulder and London: Lynne Rienner)

Brown, D. (1980) “The Political Response to Immiseration: A Case Study of Rural Ghana" Geneve Afrique, Vol XVIII, No 1

Callaghy, Thomas M. (1994) "Civil Society, Democracy, and Economic Change in Africa: A Dissenting Opinion about Resurgent Societies” in John W. Harbeson, Donald Rothchild and Naomi Chazan eds., Civil Society and the State in Africa (Boulder and London: Lynne Rienner)

(1987) "The State as Lame Leviathan: The Patrimonial Administrative State in Africa" in Zaki Ergas ed. The African State in Transition (Houndmills: Macmillan)

Campbell, Bonnie (1989) "Indebtedness in Africa: Consequence, Cause or Symptom of the Crisis?" in Bade Onimode ed. The IMF, the World Bank and the African Debt, Vol 2: The Social and Political Impact (London and New Jersey: Institute for African Alternatives and Zed)

Chazan, Naomi (1986) "Ethnicity in Economic Crisis: Development Strategies and Patterns of Ethnicity in Africa” in Dennis L. Thompson and Dov Ronen eds., Ethnicity, Politics, and Development (Boulder: Lynne Rienner)

(1982) An Anatomy of Ghanaian Politics: Managing Political Recession, 1969-1982 (Boulder: Westview)

Cohen, Abner ed. (1974) Urban Ethnicity (London: Tavistock)

(1969) Custom and Politics in Urban Africa (London: Routledge and Kegan Paul)

Coleman, James S. (1958) Nigeria: Background to Nationalism (Berkeley: University of California Press)

Corbo, V. and Webb, S.B. (1991) “Adjustment Lending and the Restoration of Sustainable Growth" Journal of International Development, Vol 3, No 2

Deng, Lual, Kostner, Markus and Young, Crawford eds. (1991) Democratization and Structural Adjustment in Africa in the 1990s (Madison: African Studies Programme, University of Wisconsin)

Despres, Leo A. ed. (1975) Ethnicity and Resource Competition in Plural Societies (The Hague: Mouton)

Duncan, Alex and Howell, John eds. (1992) Structural Adjustment and the African Farmer (London: Overseas Development Institute, James Currey and Heinemann)

ECA (1989) African Alternative to Structural Adjustment Programmes (AA-SAP): A Framework for Transformation and Recovery (Addis Ababa: ECA)

Eisenstadt, S.N. and Lemarchand, R. (1981) Political Clientelism, Patronage and Development (Beverly Hills and London: Sage)

Ekeh, Peter P. (1990) "Social Anthropology and Two Contrasting Uses of Tribalism in Africa" Comparative Studies in Society and History, Vol 32, No 4

(1975) "Colonialism and the Two Publics in Africa: A Theoretical Statement" Comparative Studies in Society and History, Vol 17, No 1 and

Osaghae, Eghosa E. eds. Federal Character and Federalism in Nigeria (Ibadan: Heinemann)

Enloe, Cynthia H. (1973) Ethnic Conflict and Political Development (Boston: Little, Brown and Company)

Erikson, Erik (1968) Identity, Youth and Crisis (New York: W.W. Norton) 
Fadahunsi, Akin (1993) "Devaluation: Implications for Employment, Inflation, Growth and Development" in Adebayo O. Olukoshi ed. The Politics of Structural Adjustment in Nigeria (London, Ibadan and Portsmouth: James Currey and Heinemann)

Faruqee, Rashid (1994) "Nigeria: Ownership Abandoned" in Ishrat Husain and Rashid Faruqee eds. Adjustment in Africa: Lessons from Country Case Studies (Washington DC: The World Bank)

Fashoyin, Tayo (1993) "Nigeria: Consequences for Employment" in Aderanti Adepoju ed. The Impact of Structural Adjustment on the Population of Africa (Portsmouth and London: Heinemann, James Currey and UNFPA)

Forrest, Tom (1993) Politics and Economic Development in Nigeria (Boulder, San Francisco and Oxford: Westview)

Gans, H. (1979) "Symbolic Ethnicity: The Future of Ethnic Groups and Cultures in America" Ethnic and Racial Studies, Vol 2, No 1

Graf, William D. (1988) The Nigerian State: Political Economy, State Class and Political System in the Postcolonial Era (London and Portsmouth: James Currey and Heinemann)

Hechter, M. and Levi, M. (1979) "The Comparative Analysis of Ethnoregional Movements" Ethnic and Racial Studies, Vol 2, No 3

Herbst, J. (1990) "The Politics of Structural Adjustment in Africa" World Development, Vol 12 , No 2

Hyden Goran (1986) “The Anomaly of the African Peasantry" Development and Change, Vol 17, No 4

Idode, John B. (1981-82) "The Administration of Community Development Projects in Bendel State of Nigeria" Quarterly Journal of Administration, Vol XVI, Nos 1 and 2

Joseph, Richard A. (1987) Democracy and Prebendal Politics in Nigeria: The Rise and Fall of the Second Republic (Cambridge: Cambridge University Press)

(1983) "Class, State and Prebendal Politics in Nigeria" Journal of Commonwealth and Comparative Politics, Vol 21, No 3

Kasfir, Nelson (1976) The Shrinking Political Arena: Participation and Ethnicity in African Politics, with a Case Study of Uganda (Berkeley: University of California Press)

Legum, Colin (1987) "Nigeria" in his ed. Africa Contemporary Record: Annual Survey and Documents 1985-1986 (New York and London: Africana)

Lema, Antoine (1993) Africa Divided: The Creation of "Ethnic Groups" (Lund: Lund University Press)

Loxley, John (1988) Ghana: Economic Crisis and the Long Road to Recovery (Ottawa: The North-South Institute)

Malloy, J. (1987) "The Politics of Transition in Latin America" in J. Malloy and M. Seligson eds., Authoritarians and Democrats: Regime Transition in Latin America (Pittsburgh: University of Pittsburgh Press)

Mkandawire, Thandika (1994) "Adjustment, Political Conditionality and Democratisation in Africa" in Giovanni A. Cornia and Gerald K. Helleiner eds., From Adjustment to Development in Africa: Conflict, Controversy, Convergence, Consensus? (New York: St. Martin's Press)

Mustapha, A. Raufu (1992) "Structural Adjustment and Multiple Modes of Livelihood in Nigeria" in Peter Gibbon, Yusuf Bangura and Arve Ofstad eds., Authoritarianism, Democracy, and Adjustment: The Politics of Economic Reform in Africa (Uppsala: Nordiska Afrikainstitutet)

Nnoli, Okwudiba (1978) Ethnic Politics in Nigeria (Enugu: Fourth Dimension) (1989) Ethnic Conflict in Africa, Working Paper 1/89 (Dakar: CODESRIA)

Nyang'oro, Julius E. and Shaw, Tim M. eds. (1992) Beyond Structural Adjustment in Africa: The Political Economy of Sustainable and Democratic Development (New York, Westport and London: Praeger) 
Ogbu, Osita M. (1991) “Farmers' Response to Structural Adjustment in Sub-Saharan Africa: The Need for Democratic Reforms" in Lual Deng, Markus Kostner and Crawford Young eds., Democratization and Structural Adjustment in Africa in the 1990s (Madison: African Studies Programme, University of Wisconsin)

Okamura, J.Y. (1981) "Situational Ethnicity" Ethnic and Racial Studies, Vol 4, No 4

Olagunju, Tunji, Jinadu, Adele and Oyovbaire, Sam (1993) Transition to Democracy in Nigeria (1985-1993) (Ibadan, London, Accra: Safari Books and Spectrum)

Olukoshi, Adebayo O. ed. (1993) The Politics of Structural Adjustment in Nigeria

(London, Ibadan, Portsmouth: James Currey and Heinemann) ed.

(1991) Crisis and Adjustment in the Nigerian Economy (Lagos: JAD)and

Nwoke, Chibuzo N. (1994) "The Theoretical and Conceptual Underpinnings of Structural Adjustment Programmes" in Adebayo O. Olukoshi, R. Omotayo Olaniyan and Femi Aribisala eds., Structural Adjustment in West Africa (Lagos: Pumark for NIIA)

Onimode, Bade (1992) A Future for Africa: Beyond the Politics of Adjustment (London: Earthscan and IFAA)

(1991) "Transcending the Politics of Adjustment" in Ben Turok ed. Debt and Democracy, Vol 3: Alternative Strategies for Africa (London: IFAA) ed. (1989) The IMF, the World Bank and the African Debt, Vol 2: The Social and Political Impact (London, New Jersey: IFAA and Zed) (1988) A Political Economy of the African Crisis (London: Zed)

Osaghae, Eghosa E. (forthcoming) “The Ogoni Uprising: Oil Politics, Minority Agitation and the Future of the Nigerian State" African Affairs

(1994a) "Towards a Fuller Understanding of Ethnicity in Africa: Bringing Rural Ethnicity Back" in his ed. Between State and Civil Society in Africa (Dakar: CODESRIA) (1994b) Trends in Migrant Political Organization in Nigeria: The Igbo in Kano (Ibadan: IFRA)

(1993) "From Benevolence to Greater Benevolence: The State and the Politics of Structural Adjustment in Rural Africa” Africa Quarterly, Vol 33

(1992) "Managing Ethnic Conflicts under Democratic Transition in Africa: The Promise, The Failure and the Future" in B. Caron, A. Gboyega and E. Osaghae eds., Democratic Transition in Africa (Ibadan: CREDU)

(1991) "A Re-Examination of the Conception of Ethnicity in Africa as an Ideology of Inter-Elite Competition” African Study Monographs, Vol 12, No 1

(1990) Ethnicity in Nigeria: The New Phase Report submitted to the Ford Foundation/Social Science Council of Nigeria Research Projects on Contemporary Development Issues in Nigeria

(1989) "The Character of the State, Legitimacy Crisis, and Social Mobilization in Africa: An Explanation of Form and Character" Africa Development, Vol XIV, No 2 (1988) "The Complexities of Nigeria's Federal Character and the Inadequacies of the Federal Character Principle in Nigeria" Journal of Ethnic Studies, Vol 16, No 3 (1986) "On the Concept of the Ethnic Group in Africa: A Nigerian Case" Plural Societies, Vol XVI

Otite, Onigu (1990) Ethnic Pluralism and Ethnicity in Nigeria (Ibadan: Shaneson C.I.) Peil, Margaret (1991) Lagos: The City is the People (London: Belhaven Press)

Post, Ken (1991) “The State, Civil Society, and Democracy in Africa: Some Theoretical Issues" in Robin Cohen and Harry Goulbourne eds. Democracy and Socialism in Africa (Boulder, San Francisco, Oxford: Westview)

Przeworski, Adam (1991) Democracy and the Market: Political and Economic Reforms in Europe and Latin America (New York: Cambridge University Press)

Rothchild, Donald (1986) "Hegemonial Exchange: An Alternative Model for Managing Conflict in Middle Africa" in Dennis L. Thompson and Dov Ronen eds., Ethnicity, Politics, and Development (Boulder: Lynne Rienner) and 
Olorunsola, Victor A. eds, (1983) State Versus Ethnic Claims: African Policy Dilemmas (Boulder: Westview)

Rothschild, Joseph (1981) Ethnopolitics: A Conceptual Framework (New York: Columbia University Press)

Saro-Wiwa, Ken (1992) Genocide in Nigeria: The Ogoni Tragedy (London Lagos Port Harcourt: Saros International)

Schildkrout, Enid (1974) "Ethnicity Among Urban Migrants in Ghana" in Abner Cohen ed. Urban Ethnicity (London: Tavistock)

Smith, Anthony D. (1981) The Ethnic Revival in the Modern World (Cambridge: Cambridge University Press)

Southall, Aidan (1988) "Small Centers in Rural Development: What Else is Development Other than Helping Your Own Hometown?” African Studies Review, Vol 31, No 3

Stack, John F. ed. (1981) Ethnic Identities in a Transnational World (Westport, London: Greenwood Press)

UNICEF (1987) Adjustment With a Human Face (Paris: UNICEF)

Usman, Bala Y. (1986) Nigeria against the I.M.F: The Home Market Strategy (Kaduna: Vanguard Publishers)

Vinod, Thomas, Chhibber Ajay, Dailami Mansoor and de Melo Jaime (1991) Restructuring Economies in Distress: Policy Reform and the World Bank (Washington DC: World Bank)

Wente-Lukas, R. (1985) Handbook of Ethnic Groups in Nigeria (Stuttgart: Studien zur Kulturekunde 74 Franz Steiner Verlag Weisbaden)

World Bank (1990) Making Adjustment Work for the Poor: A Framework for Policy Reform in Africa (Washington, DC: World Bank)

Yahaya, Shehu (1993) "State Versus Market: The Privatization Programme of the Nigerian State" in Adebayo O. Olukoshi ed. The Politics of Structural Adjustment in Nigeria (London, Ibadan, Portsmouth: James Currey and Heinemann)

Young, Crawford (1976) The Politics of Cultural Pluralism (Madison: University of Wisconsin Press) 